\title{
Do short-term rental platforms affect housing markets? Evidence from Airbnb in Barcelona ${ }^{\text {is }}$
}

\author{
Miquel-Àngel Garcia-López ${ }^{\mathrm{a}}$, Jordi Jofre-Monseny ${ }^{\mathrm{b}, *}$, Rodrigo Martínez-Mazza ${ }^{\mathrm{b}}$, Mariona Segú ${ }^{\mathrm{c}}$ \\ ${ }^{a}$ Universitat Autònoma de Barcelona and Institut d'Economia de Barcelona, Spain \\ ${ }^{\mathrm{b}}$ Universitat de Barcelona and Institut d'Economia de Barcelona, Spain \\ ${ }^{c}$ RITM, Université Paris-Saclay and Institut National d'Études Démographiques (INED), France
}

\section{A R T I C L E I N F O}

\section{JEL classification}

R10

R20

R31

Z30

\section{Keywords:}

Housing markets

Short-term rentals

Airbnb

\begin{abstract}
A B S T R A C T
In this paper, we assess the impact of Airbnb on housing rents and prices in the city of Barcelona. Examining very detailed data on rents and both transaction and posted prices, we use several econometric approaches that exploit the exact timing and geography of Airbnb activity in the city. These include i) panel fixed-effects models, where we run multiple specifications that allow for different forms of heterogeneous time trends across neighborhoods, ii) an instrumental variables shift-share approach in which tourist amenities predict where Airbnb listings will locate and Google searches predict when listings appear, iii) event-study designs, and iv) finally, we present evidence from Sagrada Familia, a major tourist amenity that is not found in the city centre. Our main results imply that for the average neighborhood, Airbnb activity has increased rents by $1.9 \%$, transaction prices by $4.6 \%$ and posted prices by $3.7 \%$. The estimated impact in neighborhoods with high Airbnb activity is substantial. For neighborhoods in the top decile of Airbnb activity distribution, rents are estimated to have increased by $7 \%$, while increases in transaction (posted) prices are estimated at 17\% (14\%).
\end{abstract}

\section{Introduction}

Tourism has grown enormously in recent decades: between 1990 and 2017, the worldwide number of international tourist arrivals increased from about 400 million to 1300 million (WTO, 2018). This pattern is particularly apparent in urban tourism; the number of visitors to the 162 most popular cities in the world has increased on average $6.5 \%$ each year between 2009 and 2018 (MasterCard, 2019). Home-sharing peer-to-peer platforms such as Airbnb have recently entered the market, partly accommodating the increased demand for tourism in cities. As a consequence, they have contributed to increasing the overlap between tourism and housing markets by allowing owners of residential properties to enter the hospitality sector.

Proponents of home-sharing platforms argue that short-term rentals provide residents with an additional source of income while decen- tralizing tourism within cities. From an economic point of view, home-sharing platforms can be seen as an efficiency improvement in markets where goods are not fully used (Barron et al., 2020). For example, empty apartments during holiday periods are efficiency losses that can be reduced through short-term rentals. However, if home-sharing platforms are used by owners to permanently shift from long-term to short-term rentals for tourists, the supply of units in the long-term market is reduced, increasing housing prices and rents. Critics of home-sharing platforms emphasize that short-term rental units in residential areas might constitute a negative externality for residents in terms of noise or uncivil behavior and cause displacement of long-term residents. ${ }^{1}$ Complaints about touristification effects and nuisances have resulted in local policy implementation that limits the expansion of platforms such as Airbnb. Such policy responses include permit requirements (Barcelona, Berlin, Paris, San Francisco, and Los

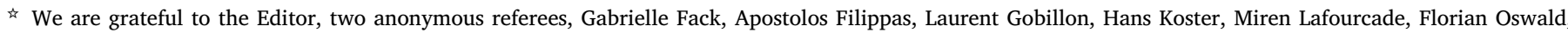

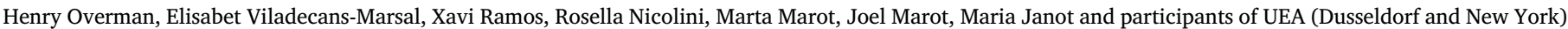

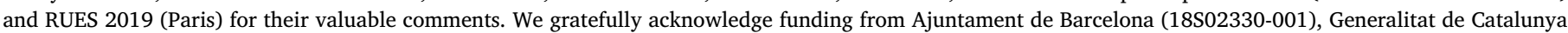

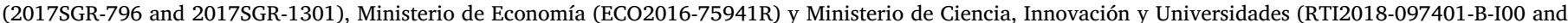

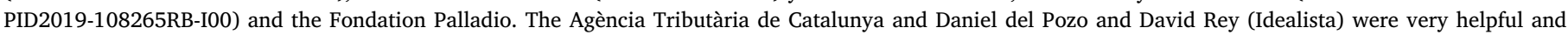
collaborative with their data.

* Corresponding author.

E-mail address: jordi.jofre@ub.edu (J. Jofre-Monseny).

1 Similarly, the hotel industry views home-sharing platforms as a threat to fair competition. Zervas et al. (2017) empirically studies the effect of Airbnb on hotel revenues. 
Table 1

Airbnb activity in 2015 in selected cities.

\begin{tabular}{lllll}
\hline & Barcelona & New York & Los Angeles & Paris \\
\hline Airbnb Listings & 16,951 & 45,260 & 30,000 & 35,000 \\
as \% of total units & 2.06 & 1.31 & 0.86 & 2.56 \\
as \% of rented units & 6.84 & 1.92 & 1.56 & 4.97 \\
Average Airbnb price/day $(€)$ & 71 & 131 & 114 & 81 \\
Long-term rent/day $(€)$ & 11 & 59 & 75 & 37 \\
Days/month for same revenue & 10 & 14 & 20 & 14 \\
\hline
\end{tabular}

Notes: Data on Barcelona comes from Cadastral Records and INCASOL, data on New York and Los Angeles comes from US Census Bureau, Zillow Rent Index and airdna, and data for Paris comes from INSEE and OLAP. All Airbnb data have been obtained through InsideAirbnb.

Angeles), limiting the rental period (Amsterdam, New York, Paris, and San Francisco), paying a rental tax (Amsterdam and San Francisco), or outlawing short-term rentals under some conditions (Berlin and New York). Despite all these local policy responses, we still have limited evidence on the effect of home-sharing platforms on housing markets.

In this paper, we analyze the effects of the arrival and expansion of Airbnb in Barcelona. Barcelona is ideal to study the effects of Airbnb on local housing markets for several reasons. First, Barcelona has experienced rapid tourism growth. The number of passengers in the city's airport increased from 20 to 47 million between 2000 and 2017. It is the 7th most visited destination city in Europe, measured by overnight visitors, and the 17th worldwide (MasterCard, 2019). Second, Airbnb accounts for the majority of short-term rental activity in the city, far ahead of its competitors. ${ }^{2}$ Third, Airbnb penetration in Barcelona is high, with Barcelona being Airbnb's 6th top destination worldwide. ${ }^{3}$

Table 1 compares the number of Airbnb listings in Barcelona, New York, Los Angeles and Paris in 2015. Despite substantial legal uncertainties regarding the use of home-sharing platforms in Barcelona, about $2.06 \%$ of all housing units are listed on Airbnb. ${ }^{4}$ This figure is higher than in New York (1.31\%) and Los Angeles (0.86\%), and slightly smaller than Paris (2.56\%). However, if we measure Airbnb listings relative to the number of rented units, the percentage for Barcelona rises to $6.84 \%$, a figure significantly higher than the other cities. ${ }^{5}$ This high penetration of Airbnb in Barcelona is likely to be explained by the (large) difference between the returns of short-term and long-term rentals. At the bottom of Table 1, we provide estimates of the difference in revenue between Airbnb and long-term rentals. In 2015, the average long-term rental price in Barcelona was $€ 11$ per night ( $€ 735$ per month), while the average Airbnb price (short-term rental) was $€ 71$ per night. An Airbnb listing yields the monthly income of a long-term rental in just 10 days of occupancy.

To guide the empirical analysis and to clarify the underlying mechanisms of the Airbnb effect on residential housing markets, we develop a stylized model where owners can decide to rent long-term to residents or short-term to tourists. The model predicts that Airbnb will increase housing prices and rents, with the effect on rents being larger than for prices. In terms of testable implications regarding mechanisms, the model predicts that Airbnb reduces the long-term supply of residential housing units.

${ }^{2}$ For Barcelona, Airbnb's market share is around 70\% according to the DataHippo Project (https://datahippo.org/es/) which collects data from several home-sharing platforms since 2017. We do not use this data-set because it does not cover the period of study.

3 'You'll never guess which city has the most Airbnb listings'. Forbes. J Bishop 2017.

${ }^{4}$ Barcelona's regulation of short-term rental platforms has not substantially changed during recent years. A city law passed in 2007 (Housing Rights Act 18/2007) states that tourist apartments that are neither primary nor secondary residences are required to have a business activity permit. When Airbnb first arrived in Barcelona around 2009, the shortterm rentals of entire apartments without a permit were illegal. Nevertheless, enforcement of the law was very low until 2016, when the number of inspections substantially increased.

${ }^{5}$ Compared to traditional tourist accommodation, the number of active listings was equal to $32 \%$ of the total number of beds in hotels in the city in 2017 .
To study the effect of Airbnb listings on residential housing markets, we combine publicly available web-scraped data on Airbnb listings in Barcelona with high-quality data on housing rents and real estate prices. We have access to i) individual-level data on the universe of transactions of second-hand apartments sold in the 2009-2017 period and ii) all posted ads for rentals and sales from a major real estate website (Idealista) that were active each December in the 2007-2017 period. We aggregate the information at the geographical level of small neighborhoods, which leaves us with a panel dataset of 221 small geographical areas that have an average population of about 7000 inhabitants.

Throughout the empirical analysis, our dependent variable is the average residual resulting from a hedonic regression in which the log of housing rents or real estate prices are regressed on time dummies and unit characteristics. In all regressions, we control for neighborhood and time fixed effects. Since Airbnb has grown the most in central parts of the city, our main identification concern is that neighborhoods that experienced higher Airbnb penetration might be simultaneously experiencing processes of urban revival. ${ }^{6}$ Aside from controlling for timevarying neighborhood socioeconomic characteristics that are associated with gentrification processes, we adopt several strategies to account for the potential unobserved confounding effects of urban revival.

First, we estimate panel fixed-effects specifications that allow neighborhoods to have different time trends. We run i) specifications that include interaction terms between baseline neighborhood characteristics (including the distance to the city centre) and a time trend (either linear or quadratic), ii) specifications that include interaction terms between these same neighborhood characteristics and (the log of) aggregate regional GDP, iii) specifications that fit neighborhood-specific time trends (either linear or quadratic), and iv) specifications on detrended data, where the outcome is measured as the deviation from its pre-2013 extended linear trend.

Second, we apply an IV strategy, where the instrument is the interaction between i) a measure of proximity to the city's tourist amenities at the neighborhood level and ii) a Google Trends measure that tracks changes in Airbnb activity over time. The proximity to tourist amenities predicts Airbnb listing locations, while searches for Airbnb in Google predict when these listings are posted. We indirectly verify the exclusion restriction by showing that proximity to tourist amenities does not predict rent and price growth in the pre-Airbnb period (i.e., before 2013).

Third, we also estimate event-study regressions. Specifically, we estimate interaction terms between year dummies and a continuous measure of Airbnb activity in 2016. This approach allows us to directly check if housing markets in neighborhoods that experienced a high Airbnb penetration after 2012 were evolving similarly prior to the expansion of Airbnb as compared to the rest of the city.

\footnotetext{
${ }^{6}$ For the US, processes of urban revival have been described and studied by BaumSnow and Hartley (2020); Couture and Handbury (2020), while Behrens et al. (2018) focus on the changes in local businesses associated with gentrification processes. GonzálezPampillón et al. (2019) provide some evidence of gentrification in the city center of Barcelona.
} 
Finally, we study rent and price dynamics around one specific location, Sagrada Familia, one of the main tourist attractions in the city. While Airbnb activity is high around Sagrada Familia, it is outside the city centre. The results for Sagrada Familia are less prone to be confounded by urban revival dynamics affecting the most central parts of the city.

All the empirical approaches yield results that are qualitatively and quantitatively similar, and are consistent with the predictions of our model. Airbnb has increased both rents and prices. Our preferred specification results suggest that 54 more active listings in a small neighborhood (about the average level in 2016) increase rents by $1.9 \%$, while transaction and posted prices increase by $4.6 \%$ and $3.7 \%$, respectively. However, our estimates imply that local impacts can be substantial in the most touristy parts of the city. Our results imply that an increase of 200 listings (the average number of listings in the top decile of the Airbnb activity distribution in 2016) increase rents by $7 \%$ and transaction and posted prices by $17 \%$ and $14 \%$, respectively. We also show that Airbnb listings reduce the number of resident households in the neighborhood.

Despite Airbnb being a recent phenomenon, there are already some research papers that estimate the effect of Airbnb on housing markets. Barron et al. (2020) and Koster et al. (2020) are the two papers that are the most similar to our study. Barron et al. (2020) look at the impact of Airbnb on rents and house prices for all cities in the US. ${ }^{7}$ Their main strategy consists of using a 'shift-share' instrument, where the time variation comes from Google Trends of 'Airbnb' searches, while the crosssectional variation is a neighborhood 'touristiness' index based on the location of restaurants. They find that a $1 \%$ increase in Airbnb listings increases rents by $0.018 \%$ and housing prices by $0.026 \%$. Koster et al. (2020) study the effects of Airbnb bans implemented by several, but not all, local governments in the Los Angeles area. Exploiting changes in prices at the administrative border, they find that banning Airbnb decreases prices by about $5 \%$.

Compared to Koster et al. (2020), our paper focuses on a different channel through which Airbnb affects housing markets. In Koster et al. (2020) the use a spatial RD design, which compares changes in prices across municipality borders following Airbnb bans. This neatly identifies the price increase of a property due to the possibility of using Airbnb. However, properties located across a border might be part of the same housing market, and, their spatial RD estimates do not capture changes in rents and prices that are caused by supply reductions. As Koster et al. (2020) point out, rents should be smooth at the border. The supply channel is of great interest from a policy perspective, as rent increases caused by Airbnb are among the main complaints made by critics of short-term rental platforms.

Calder-Wang (2020) and Almagro and Domínguez-Lino (2020) adopt structural approaches to estimate the effects of Airbnb on the welfare of heterogeneous residents. Calder-Wang (2020) develops a model where absentee landlords can choose to rent either short-term (to tourists) or long-term (to residents) and where residents can also host by temporarily renting their home. In the model, estimated with data from New York, Airbnb affects residents' welfare trough two different channels. A rent channel, that comes from rent increases, following the reduction of long-term supply, and a host channel, since residents are allowed to collect income by renting their homes. Her results show that renters' net welfare effect is negative since the rent channel dominates the host channel. She finds that rent increases are widespread across the city, even in neighbourhoods with low Airbnb activity, due to spillover effects. In terms of distributional effects, rent increases are particularly high for high-income, highly-educated people whose preferences are more aligned with tourists. Moreover, host gains are concentrated in a small

\footnotetext{
7 An earlier contribution is Sheppard and Udell (2016) that focuses on New York City. Their results suggest that doubling Airbnb in a 300-meter circle around a property translates to an increase in its value by $6 \%$ to $9 \%$.
}

fraction of residents with low hosting costs. Almagro and DomínguezLino (2020) set up a dynamic spatial equilibrium model of residential choice and estimate it with data from Amsterdam. The model features multiple endogenous amenities that include the congestion effects of tourism as well as services provided by monopolistically competitive firms. The authors emphasize that endogenizing neighborhood amenity formation is key to understand the nature and welfare consequences of spatial sorting. Unlike the structural approach of these two studies, our focus produces reduced-form estimates that are shown to be robust to multiple identification threats.

We contribute to the literature in several ways. First, we focus on a city where the difference in returns between Airbnb and long-term rentals is large, resulting in high levels of Airbnb activity. Second, we provide estimates from four different identification strategies that yield qualitatively and quantitatively similar results that cross-validate each other. This is particularly true for rental prices, where all our estimates indicate that the average impact of Airbnb on rents is between $1 \%$ and $3 \%$. Third, we have access to multiple high-quality micro-level data sets to track granular changes in housing rents, and posted and transaction prices. These micro-level data sets allow us to measure changes in rents and housing prices net of composition changes in rented or sold units, which is not possible when working with neighborhood average rents or prices. Fourth, we provide direct evidence on the supply mechanism by showing that Airbnb actually reduces the number of households living in the neighborhood. Fifth, this is the first study to carefully estimate the effects of Airbnb in the context of a large European city ${ }^{8}$ This is relevant given the underlying differences between European and US cities. For instance, European cities might have less excess capacity, where guest houses or basement apartments (below a main house) are virtually nonexistent. For the case of Barcelona, our analysis below shows that only a small proportion of housing units active on Airbnb are primary residences. Despite these differences, the results that we find are remarkably close to those found in Barron et al. (2020).

The paper is organized as follows. In Section 2, we develop the stylized model that studies the effects of short-term rentals on residential housing markets. Section 3 describes the Airbnb, rents and housing prices data and describes the most relevant variables. A description of our empirical strategies is provided in Section 4. The main results are presented and discussed in Section 5, while Section 6 contains the instrumental variables and event-study results. Finally, some concluding remarks are provided in Section 7.

\section{Theoretical framework}

In this section we develop a theoretical framework to understand how short-term rentals to tourists can affect the residential market for long-term rentals. The model also guides our empirical analysis in terms of model specification, threats to identification, estimation strategies and interpretation of the results.

\subsection{Model set-up}

There are two neighborhoods: a central neighborhood $c$ with fixed size $C$, and a suburban neighborhood $s$, with a housing supply curve which is not completely inelastic. All units in the city are owned by absentee owners. In the centre, owners can rent their units to residents (on a long-term basis) or to tourists (on a short-term basis).$^{9}$ In contrast, the suburban neighborhood $s$ only hosts residents. The masses of residents and tourists have been normalized to one and each individual consumes one unit of housing.

\footnotetext{
8 Although not the main aim in Almagro and Domínguez-Lino (2020), the authors use a shift-share instrumental variables approach that indicates that Airbnb activity increased rents in Amsterdam.

${ }^{9}$ Note that the model leaves out resident home owners as it focuses on the competition for housing between tourists and renters.
} 


\subsection{Owner choices}

Owners in neighborhood $c$ can rent their apartments through a longterm rental to a resident and obtain an annual market rent $Q^{c}$ or, alternatively, rent short-term to tourists and obtain an annual rent of $T$. Each owner $j$, who owns one unit, faces a cost $b_{j}$ to rent short-term to tourists, which reflects the legal uncertainties or the costs of running an Airbnb business. The term $b_{j}$ is heterogeneous across owners since they can differ in their risk aversion towards legal uncertainties or their access to legal services. If $T-b_{j}>Q^{c}$, the owner rents short-term to tourists, while if $T-b_{j} \leq Q^{c}$, the owner rents long-term to a resident. The cost $b_{j}$ allows $T$ to exceed $Q^{c}$ in equilibrium, which is a salient feature of the data for the case of Barcelona. In equilibrium, there is a marginal owner who is indifferent between renting to residents or to tourists, $T-b_{j}^{*}=Q^{c}$, which implies that owners with $b_{j}<b_{j}^{*}$ rent shortterm, while those with $b_{j} \geq b_{j}^{*}$ rent long-term. Hence, $b_{j}^{*}$ is the share of units in neighborhood $c$ that are rented on a short-term basis.

\subsection{Resident and tourist choices}

The utility that resident $i$ obtains in neighborhood $c$ is $U_{i r}^{c}=A_{r}-$ $Q^{c}-\alpha F_{b}\left(b_{j}^{*}\right)+e_{i r}$, where $A_{r}$ reflects the residents' valuation of amenities of neighborhood $c, Q^{c}$ is the rental price, while $\alpha F_{b}\left(b_{j}^{*}\right)$ is a term reflecting the negative externality that tourism can impose on residents due to noise or uncivil behavior. ${ }^{10,11}$ Finally, $e_{i r}$ is an idiosyncratic term reflecting the relative preference of resident $i$ to live in neighborhood $c$ as opposed to neighborhood $s$. The utility level that resident $i$ would obtain in neighborhood $s$ is $U_{i r}^{s}=-Q^{s}$, where we normalize to zero the value of amenities in neighborhood $s$. The willingness to pay of the marginal resident to live in neighborhood $c$ is $Q^{c}\left(e_{i r}^{*}\right)=A_{r}-\alpha F_{b}\left(b_{j}^{*}\right)+e_{i r}^{*}+Q^{s}$, with everyone with $e_{i r}>e_{i r}^{*}$ living in the centre and everyone with $e_{i r} \leq e_{i r}^{*}$ living in the suburbs.

The utility that tourist $i$ obtains if staying in a short-term rental in neighborhood $c$ is $U_{i t}^{c}=A_{t}-T+e_{i t}$, where $A_{t}$ reflects the tourists' valuation of amenities in neighborhood $c$, and $e_{i t}$ is an idiosyncratic term reflecting the preference of tourist $i$ to stay in a short-term rental in neighborhood c. As in Almagro and Domínguez-Lino (2020), residents and tourists might value amenities differently. Tourists have a fixed reservation utility level $U_{t}^{0}=0$, which could reflect the possibility to stay at a hotel or visit another city. The willingness to pay of the marginal tourist to stay in a short-term rental in neighborhood $c$ is $T\left(e_{i t}^{*}\right)=A_{t}+e_{i t}^{*}$, with only those tourists with $e_{i t}>e_{i t}^{*}$ staying in a short-term rental unit in the centre.

\subsection{The equilibrium units in short-term rentals}

Without loss of generality, we assume that $b_{j}, e_{i r}$ and $e_{i t}$ are $U \sim(0$, 1 ), which simplifies the market clearing conditions in neighborhood $c$. $1-e_{i r}^{*}$ and $1-e_{i t}^{*}$ are the shares of residents and tourists who stay in the central neighbourhood $c$. We write $C b_{j}^{*}=1-e_{i t}^{*}$ which ensures that demand for short-term rentals equals its supply, while market clearing for long-term rentals implies $C\left(1-b_{j}^{*}\right)=1-e_{i r}^{*}$. In neighborhood $s$, the long-term rental price is assumed to be an increasing function of its population. Specifically, we posit that $Q^{s}=\gamma e_{i r}^{*}$, with $\gamma>0$. Combining the market clearing conditions, the willingness to pay of the marginal resident and tourist, $Q^{c}\left(e_{i r}^{*}\right)$ and $T\left(e_{i t}^{*}\right)$, and the definition of the marginal

\footnotetext{
10 Tourism as a negative externality is in line with the local population's perception of tourism as a negative phenomena in Barcelona. This is documented by an opinion poll made by local authorities since 2011, which surveys citizen perception of Barcelona's most important problems. In this poll, tourism was mentioned, on average, as the city's fourth largest problem during the entire period, reaching the top ranking in 2017.

11 Almagro and Domínguez-Lino (2020) posit that tourism affects residents through a direct negative effect and indirectly by changing the availability of non-tradable goods and services such as child care facilities.
}

owner, $T-b_{j}^{*}=Q^{c}$, we obtain the share of owners that rent short-term to tourists in neighborhood $c$ :

$b_{j}^{*}=\frac{\left(A_{t}-A_{r}\right)+C-\gamma(1-C)}{2 C+(1-\alpha)+\gamma(C)}$

Eq. 1 indicates that the main driver of the penetration of Airbnb in a central neighborhood is the tourists' valuation of amenities relative to the resident's valuation $\left(A_{t}-A_{r}\right) .^{12}$

\subsection{Rental prices}

The equilibrium price of long-term rentals can be obtained by inserting the market clearing conditions $C\left(1-b_{j}^{*}\right)=1-e_{i r}^{*}$ and $Q^{s}=\gamma e_{i r}^{*}$ in the residents' willingness to pay function:

$Q_{c}=(1-C)(1+\gamma)+A_{r}+(C+\gamma C-\alpha) b_{j}^{*}$

Eq. 2 indicates that the number of units in the short-term rental market affect long-term rents through three different mechanisms. First, one additional unit in the short-term market reduces the number of longterm residents, which mechanically increases the willingness to pay of the marginal resident as the market clearing condition reveals. Reducing the supply of long-term units increases prices. The second term is a second order general equilibrium effect. An increase in $b_{j}^{*}$ displaces residents from neighborhood $c$ to $s$, increasing rental prices in the suburbs as equation $Q^{s}=\gamma e_{i r}^{*}$ reveals. Rents can increase in areas with little to no Airbnb listings as emphasized in Calder-Wang (2020). A higher rental price in neighborhood $s$ makes neighborhood $c$ relatively more attractive, further increasing rents in neighborhood $c$. Finally, a marginal increase in $b_{j}^{*}$ means higher negative externalities, which contribute to lower long-term rents. Provided that these externalties are not too large, the overall effect of Airbnb on rents will be positive.

\subsection{Housing prices}

To relate rents and housing prices, we follow the approach of Barron et al. (2020). The market is assumed to be in a steady state, and the price of a housing unit $\left(P^{c}\right)$ is given by the present value of discounted cash flows to the landlord:

$$
\begin{aligned}
P^{c} & =\sum_{t=1}^{\infty} \delta^{t}\left[\left(1-b_{j}^{*}\right) Q^{c}+\int_{0}^{b_{j}^{*}}\left(T-b_{j}\right) d b_{j}\right] \\
& =\frac{1}{1-\delta}\left[Q^{c}+\left(T-Q^{c}\right) b_{j}^{*}-\frac{\left(b_{j}^{*}\right)^{2}}{2}\right]
\end{aligned}
$$

Assuming $\delta$ as the discount factor, the cash flow in each period reflects the fact that $1-b_{j}^{*}$ units are rented long-term at price $Q^{c}$, and $b_{j}^{*}$ units are rented in the short-term market at rate $T$ paying the cost $b_{j}$. Eq. 3 indicates that the effects of Airbnb on housing prices $\left(P^{c}\right)$ will be larger than those on rents $\left(Q^{c}\right)$, as part of the stock available for rent obtains a return of $T-b_{j}$ that is higher than $Q^{c}$.

\subsection{Implications for the empirical analysis}

Eqs. 2 and 3 motivate our empirical analysis consisting of relating changes in housing rents or prices with changes in Airbnb activity at the neighborhood level. From the theoretical framework developed here, we draw five implications for the empirical analysis.

First, the model predicts that Airbnb activity increases rents and prices, with the effect on prices being larger in absolute value.

Second, inspecting Eqs. 1-3 reveal the main identification threat faced in the empirical analysis. The effect of Airbnb activity on residential housing markets will be biased if neighborhoods where Airbnb

\footnotetext{
${ }^{12}$ For $0 \leq b_{j}^{*} \leq 1$, it has to be the case that $\gamma(1-C)-C \leq\left(A_{t}-A_{n}\right) \leq C+1-$ $\alpha+\gamma$.
} 
penetration is high are simultaneously experiencing changes in the residents' willingness to pay. It could be that neighborhoods where $A_{t}$ is high are becoming increasingly popular among residents. Central neighborhoods where Airbnb activity is higher are going through gentrification processes. We will extensively address these concerns in the empirical analysis.

Third, besides the increase in rents (and prices), the model indicates that Airbnb reduces the supply of units in the long-term rental market. As a consequence, the model predicts that Airbnb displaces residents. To test the model's main mechanism we will also estimate the effect of Airbnb activity on the number of resident households.

Fourth, as we have seen above, Eq. 1 predicts that the penetration of Airbnb is (partly) determined by the presence of neighborhood amenities that are more important to tourists than they are to residents. In Section 4.2 we document that, the proximity to relevant tourist attractions is a strong predictor of Airbnb activity at the neighborhood level. This observation motivates the instrumental variables strategy developed in Section 4.2.

Fifth, our empirical analysis essentially estimates the effect of Airbnb by comparing changes in rents (or prices) between neighborhoods with high versus low Airbnb activity. Subtracting $Q^{s}$ from Eq. 2 yields:

$Q^{c}-Q^{s}=(1-C)+A_{r}+(C-\alpha) b_{j}^{*}$

Eq. 4 reveals that rent comparisons between neighborhoods with different levels of Airbnb penetration provides a lower bound of the total effect of Airbnb. Differences in rents (or prices) net-out the second-order general equilibrium effects that increase rents and prices throughout the city.

\section{Data and variables}

\subsection{Neighborhood definition}

Our geographical unit of analysis is the Basic Statistical Area (BSA). BSAs are built and used by the Barcelona City Hall for statistical purposes. There are a total of 233 BSAs with an average of 7122 inhabitants, but due to data restrictions we keep 221 BSAs in our sample. We believe that BSAs are the appropriate neighborhood definition, as they are designed to contain population with similar socio-economic characteristics and their size is sufficient to generate meaningful measures of housing rents and prices for neighborhoods over time.

\subsection{Airbnb}

To measure Airbnb activity, we use information extracted directly from the Airbnb website. InsideAirbnb is a dataset collected at different points in time by Murray Cox, an independent Internet user who has made it publicly available. For Barcelona, it contains 21 data points between April 2015 and February 2018. ${ }^{13}$ Each listing has information on the host ID, geographical coordinates, room characteristics, date the host registered, and date of each guest review. Even though Airbnb is not the only home-sharing platform active in the city, we consider that its listings are a good proxy for the short-term rental market. Its market share is by far the highest among its competitors and most short-term rentals are advertised through more than one platform simultaneously, implying that adding listings from a second platform would cause significant double counting.

For our purposes, it is crucial to identify a listing's active period. Even though the information started being scraped in early 2015, by exploiting the date of each review, we are able to reconstruct the listing's

\footnotetext{
${ }^{13}$ Details about the website can be accessed through http://insideairbnb. com/about.html.
}

activity prior to 2015 (as well as in between the rest of the data points). This strategy is supported by the fact that, according to Airbnb, $72 \%$ of guests leave a review. ${ }^{14}$ We follow Zervas et al. (2017) and consider that a listing is active in a given quarter if it has received at least one review during that quarter. ${ }^{15}$

The potential consequences of Airbnb might be very different if the platform is used to rent out excess capacity (home-sharing), or if units are rented short-term through Airbnb all year long. We label listings that correspond to this second category as 'commercial'. Listings in Airbnb are entire apartments, private rooms or shared rooms. We consider multi-hosted properties (host has more than one listing) and singlehosted entire apartments with a minimum of 5 reviews per quarter to be commercial. This definition is clearly conservative, as many entire properties are rented as separate private rooms. ${ }^{16}$ Despite this, more than $75 \%$ of all listings in every single year in our sample correspond to this commercial category. Although some genuine home-sharing exists on the platform, Airbnb in Barcelona is mostly a commercial activity.

\subsection{Rents and prices}

We use two sources of data to obtain information on rents and prices at a fine spatial level. In particular, we have two measures for prices (transaction prices and posted prices) and one measure for rents (posted rents). For transaction prices, we use data from the Catalan Tax Authority from transaction tax records, which includes the price, exact location, date of transaction, size of the housing unit, year of construction, and a variable reflecting the quality of the dwelling. We have the universe of transactions that occurred in Barcelona during the period 2009-2017. ${ }^{17}$ We label this dataset ITP (Impuesto sobre Transmisiones Patrimoniales) or transaction prices.

For posted rents and prices, we use information from the online real estate portal Idealista. With more than one million ads and an average of 17 million weekly views, Idealista is by far the most important Spanish real estate portal. Idealista provided us with all ads that were active for the city of Barcelona in December of every year for the period 2007$2017^{18,19}$ The data include the exact location, the posted rent or price and the size of the unit, among other characteristics ${ }^{20}$

Having two measures of prices is useful because both transaction and posted prices have advantages and disadvantages. Posted prices might differ from final prices since bargaining is a regular part of the process. Official transaction prices should, in principle, measure prices more precisely. However, in practice, the transaction (ITP) data have two limitations. First, there might be a non-negligible time lapse between the

\footnotetext{
14 Although some guests do not leave a review, there are no reasons to believe that the percentage of guests that leave a review changes non-randomly across space or time.

15 An alternative approach would be to use the entry date and assume that listings never exit, which is the preferred method in Barron et al. (2020). In the case of Barcelona, we consider that this approach is problematic. First, approximately $25 \%$ of all listings do not have any reviews at all. Second, the entry date indicates the time when the host registered. If the host has multiple listings (which is the case for the majority of listings in Barcelona), it is not possible to know the entry date of each listing.

16 This practice increased after July 2016. Short-term rentals of entire apartments without a permit is illegal, but enforcement was very low before July 2016. It is less clear if renting a private room is also against the law, and in practice, enforcement with respect to private rooms has been low throughout the period we study.

17 We keep only those sales transactions with a declared value of less than $10,000,000$ euros.

18 We have dropped the following data: sales ads with posted prices below 10,000 euros and those of less than 20 square meters, and we drop all ads with monthly rents below 100 euros or above 30,000 euros.

19 Idealista's monthly aggregate data for Barcelona show little seasonality, indicating that using December data should not be a limitation in our context.

${ }^{20}$ Other characteristics that are available and that we use are number of floors, number of rooms, presence of air-conditioning, lift and boxroom, and whether it is a studio, penthouse, or duplex.
} 


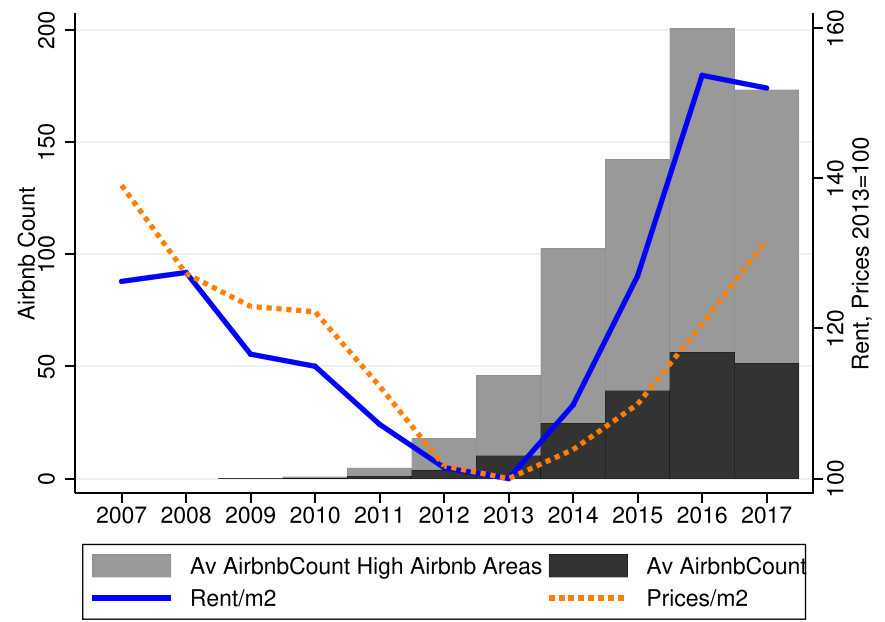

Fig. 1. Airbnb listings, rents and prices: 2007-2017. Notes: This graph plots the evolution over time of the BSA averages in Airbnb listings, rents and posted prices (per square meter) for the period 2007-2017. Rents and prices are normalized to their 2013 value. The dark gray bars represent the average Airbnb listings for all BSA, while the light gray bars depict the average listings for High Airbnb Areas (BSAs in the top decile of the Airbnb listings distribution in 2016).

date at which parties agree on a price and the date when the ITP tax is paid. Second, there is some fraud in the ITP tax that consists of underreporting the ITP price and the tax base. For rents, we cannot compare posted to actual rents. However, Chapelle and Eymeoud (2018) show, in the French context, that bargaining is less of an issue for rents and that online posted prices are a good measure of actual rents.

\subsection{Descriptive statistics}

In Fig. 1, we plot the evolution over time of Airbnb activity, together with that of rents and prices. Airbnb experienced a very rapid increase from its first entrance in 2009 up to 2016, when the growth stopped because of City Hall's increased efforts to reduce tourist apartments operating without a license. In 2016, the average BSA had 54 listings, while High Airbnb Areas (those BSAs in the top decile) had an average of 200 active listings. In these areas of the city, approximately $5 \%$ of all housing units are listed on Airbnb. The substantial variation in Airbnb activity across neighborhoods is further explored in Fig. 2, which shows the distribution of Airbnb listings across BSAs for the last quarter of 2016. Airbnb activity is higher around the city center and, to some extent, along portions of the beach line or around the Sagrada Familia. Airbnb activity is low in many other parts of the city.

The evolution of housing rents and prices in the period we study is turbulent. Following the financial crisis and the burst of the Spanish housing bubble, rents and prices fell until 2013, when they started recovering as the economy started to grow. While prices reached pre-crisis levels towards the end of the period, rents surpassed pre-crisis levels around 2015 and kept rising. During this period, housing affordability was one of the main concerns among residents. ${ }^{21}$ The recovery of rents and prices coincides in time with the return of economic growth and the expansion of Airbnb. We address the endogeneity concerns related to this coincidence in the empirical section.

We complement the data on rents, prices and Airbnb listings with a comprehensive set of socioeconomic BSA characteristics including population, age distribution, relative income index, average household size, unemployment level and the percentage of foreign population. In Table 2, we report descriptive statistics. We present the BSA means for

${ }^{21}$ See 'El acceso a la vivienda, el principal problema de los barceloneses' Macedo, G., October 2010.

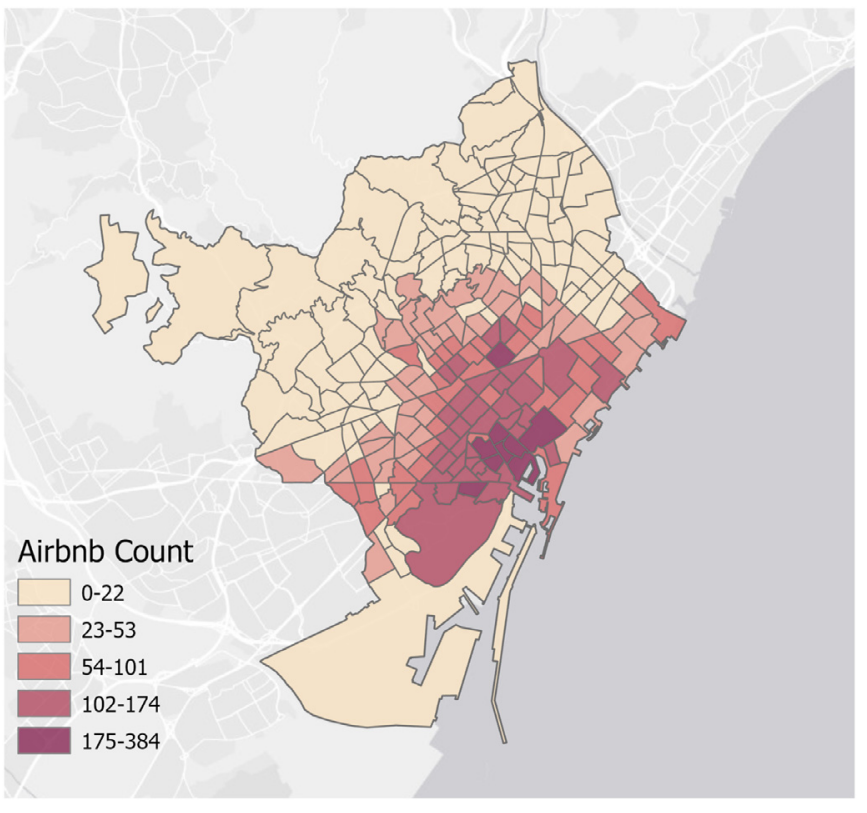

Fig. 2. Airbnb activity across BSAs in 2016. Notes: This graph plots the number of active Airbnb listings in the fourth quarter of 2016 at the BSA level.

the years 2012 and 2016 for two different samples: all BSAs and High Airbnb Areas (BSAs in the top decile of the Airbnb listings distribution in 2016).

\section{Empirical strategies}

\subsection{Baseline specification}

Our main analysis consists of estimating the following fixed-effects specification (and variants of it):

$\log \left(Y_{n, t}\right)=\beta$ Airbnb Count $_{n, t}+\gamma X_{n, t}+\tau_{t}+\mu_{n}+\varepsilon_{n, t}$

where $Y_{n, t}$ is our measure of housing rents or prices at the BSA level, Airbnb Count ${ }_{n, t}$ is the number of active listings at time $t$ in BSA $n, \tau_{t}$ are time fixed-effects, and $\mu_{n}$ are BSA fixed effects that account for timeinvariant neighborhood characteristics. Our dependent variable $\log \left(Y_{n, t}\right)$ is the average residual at the BSA-time period level of a (micro-level) regression in which log rents (or log housing prices) are regressed on time dummies and unit characteristics. ${ }^{22}$ This controls for price changes across neighborhoods that could be explained by changes in the composition of units rented or sold across BSAs and over time. For example, it allows us to control for BSAs that might have a growing proportion of high-end apartments being sold or rented over time. Throughout the regression analyses, we weight BSA-time cells by the relevant number of ads or sales. Standard errors are clustered at the BSA level to account for serial correlation within panel units (Bertrand et al., 2004).

Our main concern regarding identification is that neighborhoods with the most Airbnb activity growth during our period of study might be experiencing processes of sociodemographic change, which might have a direct impact on housing rents and prices. Airbnb has grown the most in central parts of the city that have also been experiencing processes of urban revival in the last two decades. We adopt several

\footnotetext{
${ }^{22}$ We construct a panel on the BSA-year (data from Idealista) and BSA-quarter (transaction prices). Unit characteristics in the Idealista database are size, number of floors, number of rooms, air-conditioning, lift and boxroom, and whether it is a studio, penthouse, or duplex. In the ITP database, dwelling characteristics are size, year of construction, and a variable reflecting the quality of the dwelling (with scale 1 to 8).
} 
Table 2

Descriptive statistics: Variables' means across BSAs for 2012 and 2016.

\begin{tabular}{|c|c|c|c|c|}
\hline & \multicolumn{2}{|l|}{2012} & \multicolumn{2}{|l|}{2016} \\
\hline & $\begin{array}{l}\text { All } \\
\text { BSAs }\end{array}$ & $\begin{array}{l}\text { High } \\
\text { Airbbb Areas }\end{array}$ & $\begin{array}{l}\text { All } \\
\text { BSAs }\end{array}$ & $\begin{array}{l}\text { High } \\
\text { Airbnb Areas }\end{array}$ \\
\hline Airbnb Count & 2.79 & 13.35 & 47.84 & 178.58 \\
\hline Rent $\left(€ / m^{2}\right)$ & 11.83 & 12.93 & 16.39 & 20.19 \\
\hline Posted Price $\left(€ / \mathrm{m}^{2}\right)$ & 3250 & 3338 & 3753 & 4282 \\
\hline Transaction Price $\left(€ / \mathrm{m}^{2}\right)$ & 2269 & 2356 & 2619 & 3027 \\
\hline Population & 6978 & 7750 & 6973 & 7514 \\
\hline Population Density & 0.03 & 0.04 & 0.03 & 0.04 \\
\hline Mean Age & 43.36 & 42.10 & 43.69 & 42.08 \\
\hline$\%$ of Foreign Population & 0.18 & 0.32 & 0.17 & 0.33 \\
\hline Household Size & 2.47 & 2.41 & 2.48 & 2.41 \\
\hline Unemployment Rate & 10.48 & 10.81 & 7.80 & 7.83 \\
\hline Income Index & 98.37 & 96.48 & 102.78 & 104.58 \\
\hline
\end{tabular}

Notes: Columns 1 and 3 report the mean for all BSAs in 2012 and 2016. Columns 2 and 4 report the means of High Airbnb Areas (BSAs in the top decile of the Airbnb activity. distribution in 2016).

strategies to control for the potential confounding effects of gentrification.

First, we introduce in Eq. 5 a set of time-varying controls at the BSA level $\left(X_{n, t}\right)$; average age, log of population density, average household size, unemployment rate, relative income, and percentage of foreign residents. Since this equation includes BSA-fixed effects, this allows us to control for yearly changes in variables associated with processes of gentrification. In some specifications, we allow for neighborhoods with different characteristics to have different time trends (linear or quadratic). We do so by introducing, as additional regressors, interaction terms between the time trend and the control variables measured in 2012, i.e., $X_{n, 2012} \times t$ in the linear case or $X_{n, 2012} \times t$ and $X_{n, 2012} \times t^{2}$ in the quadratic case. In this specification, we also include the interaction term between the time trend and the distance to the city center. ${ }^{23}$ This would allow, for instance, more central neighborhoods to have a steeper time trend.

Second, in a more data demanding approach, we include BSAspecific time trends (linear or quadratic). Specifically, we add $\rho_{n} \times t$ interaction terms for the linear case and $\rho_{n} \times t+\psi_{n} \times t^{2}$ for the quadratic case. This is a very flexible specification since it allows each BSA to have its own time trajectory in housing rents and prices. Here, the variations that we exploit are deviations from each BSA's own specific linear (or quadradic) time trend.

If Airbnb affects not only levels but also trends of these variables, including BSA-specific time trends would not be appropriate since it would capture both the effect of Airbnb and BSA-specific time trends (Wolfers, 2006). We resort to a detrending procedure previously applied in the taxation (Kleven et al., 2014) and minimum wage (Monras, 2019) literatures and estimate linear time trends using data prior to 2013 only (i.e. the pre-Airbnb period). We estimate the following two equations at a neighborhood-time level:

$\log \left(Y_{n, t}\right)=\mu_{n}+\tau_{t}+\rho_{n} \times t+\epsilon_{n, t}$, for $t \leq 2012$

$\widetilde{\log \left(Y_{n, t}\right)}=\beta$ Airbnb count ${ }_{n, t}+\gamma X_{n, t}+\tau_{t}+\varepsilon_{n, t}$, for all $t$

The first equation estimates the outcome based on BSA dummies, time dummies, and BSA specific linear time trends for the years up to 2012. Based on these OLS coefficients, we predict $\log \left(Y_{n, t}\right)$ for the entire sample years and compute the residuals, $\widetilde{\log \left(Y_{n, t}\right)}$. In the second stage (Eq. 7), we regress these detrended residuals against Airbnb listings, time dummies and the time-varying controls $\left(X_{n, t}\right)$.

${ }^{23}$ Distance to the city center is measured as the distance from Plaça Catalunya (the main city square) to the centroid of each BSA.

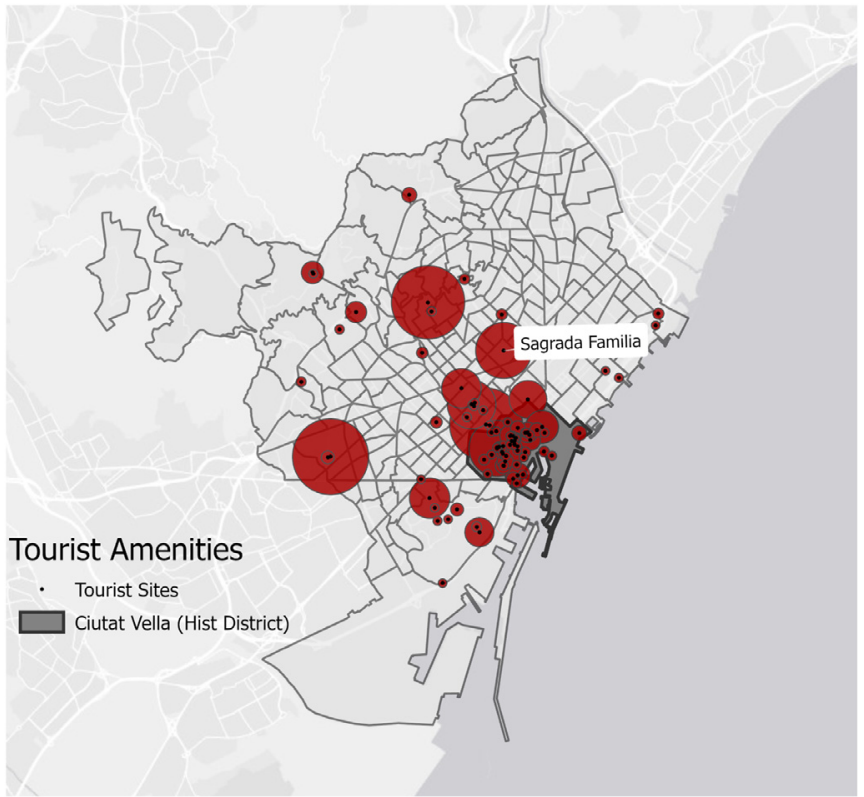

Fig. 3. Location of tourist amenities. Notes: Location of tourist amenities across the city, the size of the circles is proportional to the number of reviews. The darker area shows the city's historical district.

\subsection{Instrumental variables fixed-effects models}

As an alternative approach to tackle the endogeneity of Airbnb location, we also estimate Eq. 5 through a Two-Stage Least Squares regression. Our theoretical model indicates that short-term rentals locate in areas where tourist amenities are high. Following this prediction, we use a shift-share variable as an instrument that combines i) cross-sectional variation across BSAs in tourist amenities and ii) aggregate time variation in Airbnb activity.

For the cross-sectional 'share' component of the instrument, we build an index that measures proximity to tourist amenities. Our instrument aims to capture the set of amenities that tourists enjoy while not being of particular interest to residents. We use TripAdvisor to produce a complete list of the city's tourist amenities. ${ }^{24}$ We geolocate these amenities

\footnotetext{
${ }^{24}$ TripAdvisor is a website that offers tourism-related content. According to the site, it currently has over 390 million monthly unique visitors. We exclude the more endogenous and less historical amenities such as areas known for restaurants, bars or clubs.
} 


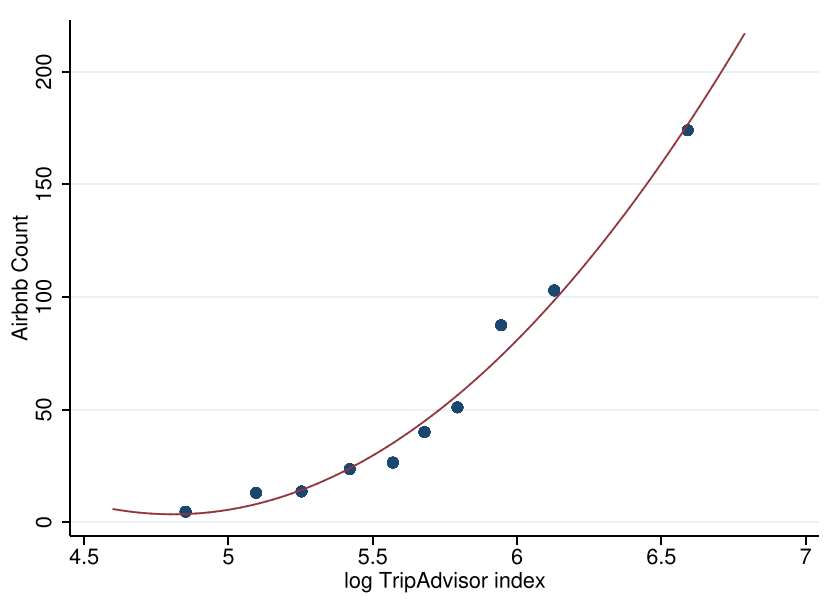

(a) Airbnb activity and tourist amenities

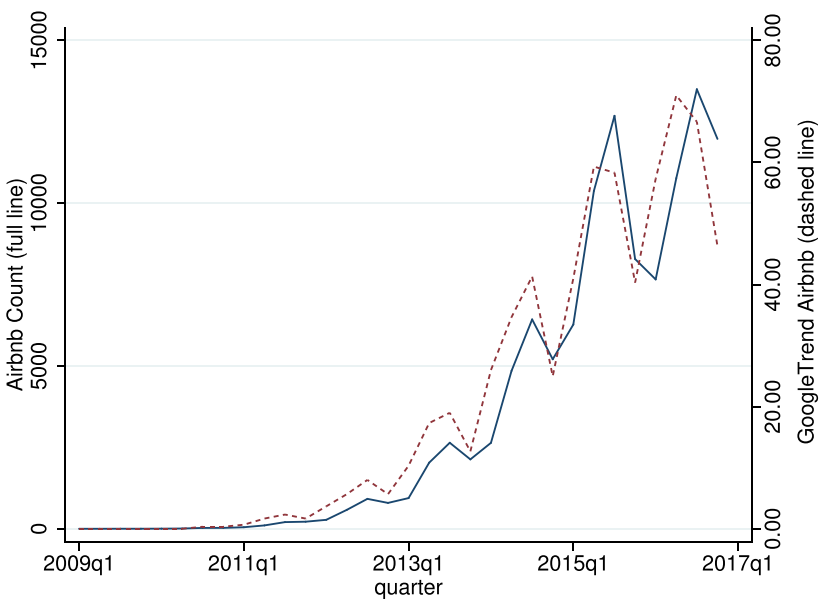

(b) Airbnb activity and Google Trends searches

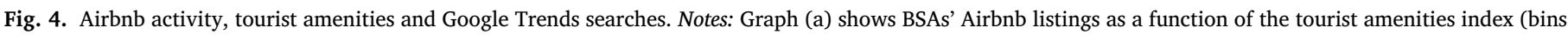

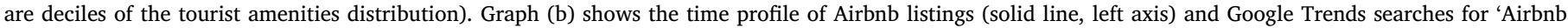
Barcelona' (dashed line, right axis).

and collect the number of Google reviews of each attraction. We use the number of reviews to weight the relative importance of each site. ${ }^{25}$ Our measure of tourist amenities is built as follows:

Tourist Amenities $_{n}=\sum_{k} \frac{1}{\text { dist }_{n, k}} \times$ Reviews $_{k}$

where $k$ indicates the amenity, dist $t_{n, k}$ is the distance in meters between the centroid of each BSA $n$ and amenity $k$, and Reviews $s_{k}$ is the number of Google reviews. Fig. 3 shows the location of these amenities, where the size of each circle is proportional to the number of reviews.

As the 'share' component of the instrument, the tourist amenities index should predict where Airbnb listings will appear. Panel a) in Fig. 4 plots this relationship by binning the data for deciles of the tourist index distribution. The graph clearly shows that BSAs that are closer to tourist amenities tend to show the highest number of Airbnb listings. This relationship can be rationalized by the model of Section 2 . Tourist amenities $\left(A_{t}\right)$ increase the tourists willingness to pay which increases both Airbnb prices (T) and Airbnb activity $\left(b_{j}^{*}\right)$. In Fig. A.1 in the Appendix, we show that neighborhoods with high levels of Airbnb activity have more expensive Airbnb listings.

Turning to the 'shift' component of the instrument, we follow Barron et al. (2020) and use worldwide searches in Google for the term 'Airbnb Barcelona'. This variable is measured at a monthly level and is normalized to 100 for the month with the highest number of searches. Panel b) of Fig. 4 shows that the number of Google Trends searches for 'Airbnb Barcelona' tracks the time variation in Airbnb activity very well.

The rationale behind the instrument works as follows. The proximity to tourist amenities predicts where Airbnb listings locate, while searches in Google Trends for the term 'Airbnb Barcelona' predict when listings appear. Fig. 4 provides suggestive evidence of the relevance of the instrument. We also test for this in the first stage regressions.

As for the exclusion restriction, recent research on shift-share instruments indicates that the main identification threats are related to the 'share' component of the instrument (Goldsmith-Pinkham et al., 2020). Since our specifications contain a BSA fixed effect, instrument validity hinges on the assumption that the cross-sectional 'share' component, proximity to tourist amenities, is only correlated with changes in housing rents and prices through Airbnb listings. For example, our instrument would be invalid if residents' valuation of proximity to tourist amenities (or any other BSA characteristic that correlates with it) changes over

\footnotetext{
${ }^{25}$ Although TripAdvisor also provides reviews, Google has more.
}

the study period for a reason other than the presence of tourism. If the instrument is valid, proximity to tourist amenities should not explain changes in housing rents and prices prior to the arrival of Airbnb. We address this issue at length below.

\subsection{Event study plots}

We conduct an event study exercise, using the following regressions:

$\log \left(Y_{n, t}\right)=\sum_{t \neq 2012} \delta_{t} \times$ AirbnbCount $_{n, 2016}+\gamma X_{n, t}+\mu_{n}+\tau_{t}+\varepsilon_{n, t}$

where AirbnbCount $_{n, 2016}$ is the number of listings in BSA $n$ in 2016. Like in previous regressions, we include time and BSA fixed effects and timevarying characteristics $\left(X_{n, t}\right)$. We estimate AirbnbCount ${ }_{n, 2016} \times$ year interactions, leaving 2012 as the base year. This approach allows us to estimate the yearly effect of having one additional listing in 2016. Again, we choose 2012 as the last pre-Airbnb year as, starting in 2013, Airbnb's activity became more significant. This exercise allows us to check if, prior to the arrival of Airbnb, areas that will experience higher Airbnb activity display similar trends in housing rents and prices compared to other neighborhoods.

\subsection{Evidence from Sagrada Familia}

In our last empirical strategy, we will focus on Sagrada Familia, one of the main tourist amenities in the city. It is one of the three major tourist amenities not found in the city centre as shown in Fig. 3. The other two non-central hotspots are Camp Nou (north-west of city centre) and Parc Güell (north-west of Sagrada Familia). Fig. 2 shows that only the area around Sagrada Familia has a high level of Airbnb activity, possibly because Camp Nou and Parc Güell are too far from the city centre. Unlike the most central parts of the city, the area around Sagrada Familia is an upper-middle class residential neighborhood. In 2000, this area was ranked 14 out of 38 broad neighborhoods by relative family income ${ }^{26}$. Its position in this ranking was 13 in 2008, indicating that this area was not experiencing gentrification in the pre-Airbnb period ${ }^{27}$ Sagrada

\footnotetext{
${ }^{26}$ Before 2008, income is only available for 38 broad neighborhoods

${ }^{27}$ Similarly, the share of population between 20 and 34 years, which is another indicator associated with gentrification, has also remained stable over the same period in the Sagrada Familia area. It was equivalent to $26 \%$ in 2000 and to $27 \%$ in 2008 .
} 


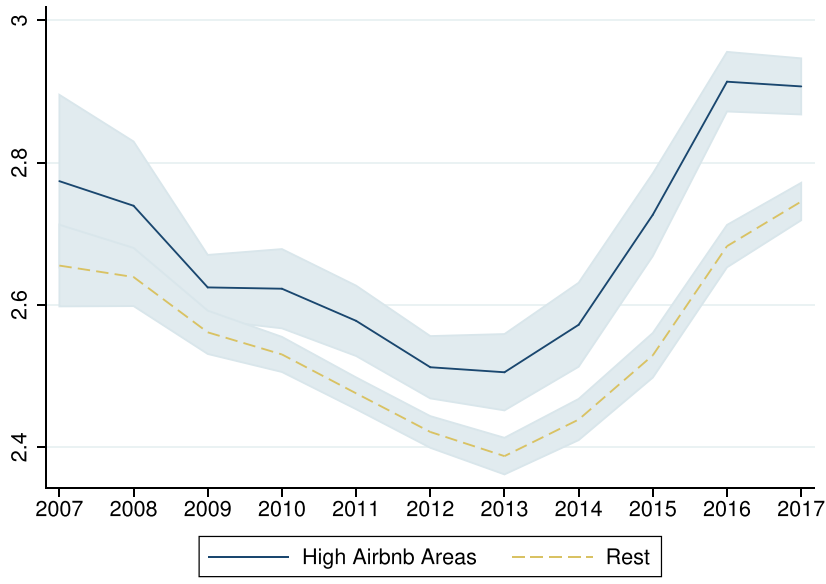

(a) Rents

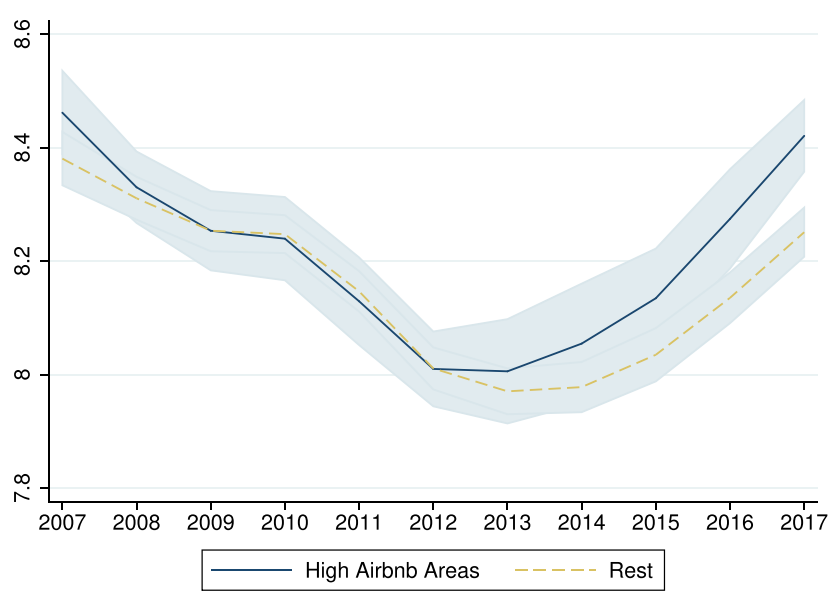

(c) Posted Prices

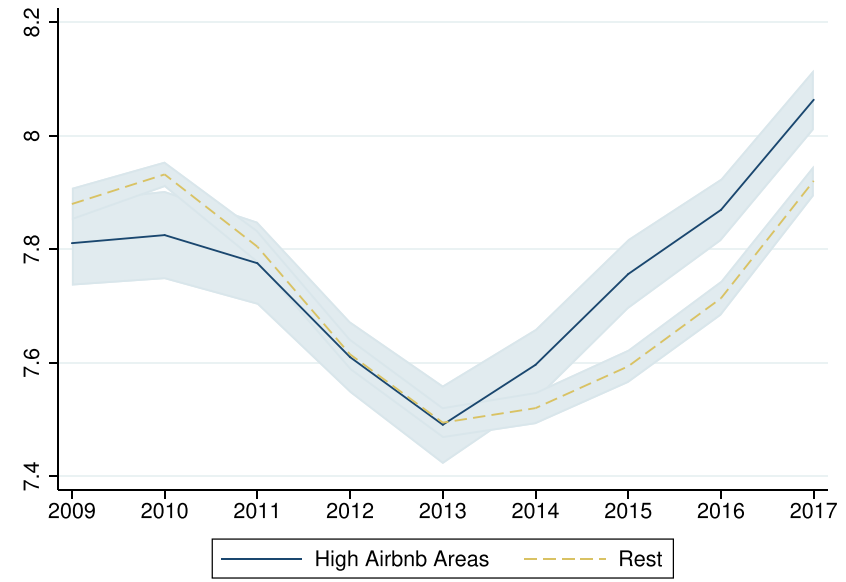

(b) Transaction Prices

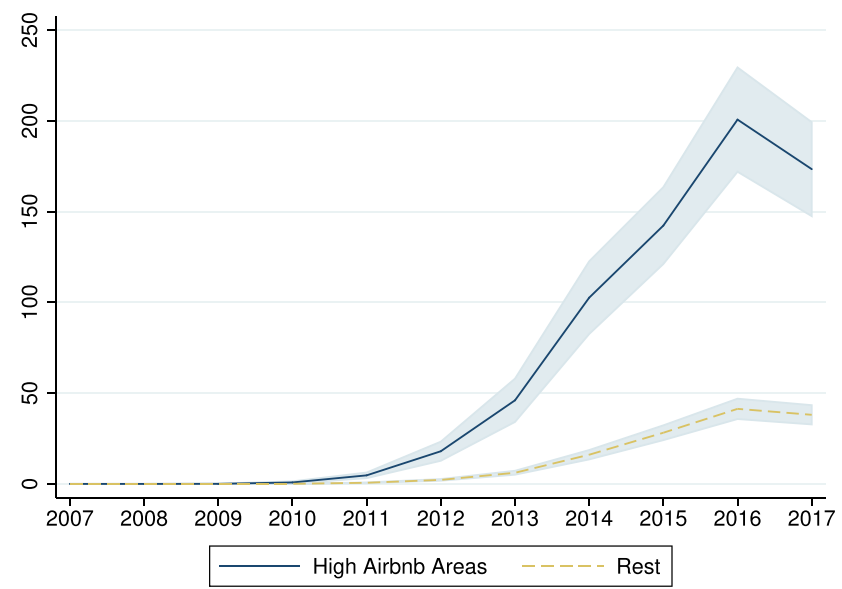

(d) Airbnb Count

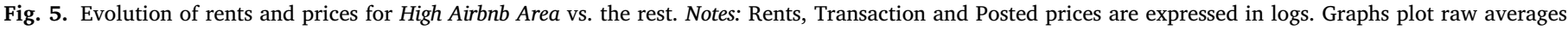
and the appropriate confidence intervals. High Airbnb Area are BSAs in the top decile of the Airbnb listings distribution in 2016.

Familia provides us a setting to study the effects of short-term rentals where concerns regarding the confounding effects of urban revival are diluted.

First, we estimate Eq. 5 by Two-Stage Least Squares where the instrument is the interaction term between the inverse distance to Sagrada Familia (1/distSF $\left.{ }_{n}\right)$ and our measure of Google Trends searches. In this case, proximity to this particular attraction predicts the location of Airbnb listings, while, as before, Google Trends predicts the timing of Airbnb arrival and expansion. We argue that this is an exogenous instrument since it is unlikely that residents' preferences to locate close to Sagrada Familia had change during the period 2007-2017 for a reason other than tourism.

Second, we also replicate our event-study design but focus on the proximity to Sagrada Familia as a predictor of Airbnb activity. We estimate $1 /$ distSF $_{n} \times$ year interactions, while controlling for the usual neighborhood characteristics and fixed effects.

$\log \left(Y_{n, t}\right)=\sum_{t \neq 2012} \delta_{t} \times \frac{1}{d i s t S F_{n}}+\gamma X_{n, t}+\mu_{n}+\tau_{t}+\varepsilon_{n, t}$

This strategy is useful to determine whether BSAs at different distances (measured in kilometers) to Sagrada Familia experience similar trends in rents and prices before and after the arrival of Airbnb.

\section{Main results}

\subsection{Graphical evidence}

Before proceeding to the regression results, in Fig. 5, we show graphical evidence of the effect of Airbnb on housing markets. We plot raw average (log) prices and rents series over time for High Airbnb Areas (BSAs in the top decile of Airbnb listings distribution in 2016) versus the rest. In Panel (a) we graph rents, while in Panels (b) and (c), we show corresponding graphs for transaction prices and posted prices, respectively. For completeness, in Panel (d), we plot our measure of Airbnb activity.

The levels of both rents and prices tend to be higher in BSAs with more Airbnb activity. While the series for the period before 2012 appear fairly parallel, the gaps in rents and prices seem to widen, with the expansion of Airbnb in 2013 and onwards, especially for rents and transaction prices, where the divergence is more noticeable. In the first three figures, the difference between the two groups is statistically significant at the end of the period, while this is not the case for the first years. Finally, in Panel (d), we report the evolution of the count of Airbnb listings by group. While the number of listings increased drastically for the High Airbnb Areas, the increase was very modest for the other BSAs, reflecting fact that Airbnb is highly concentrated in particular areas of the city. 
Table 3

Impact of Airbnb on rents and prices - Baseline Specifications.

\begin{tabular}{|c|c|c|c|c|c|c|c|c|c|}
\hline & (1) & (2) & (3) & (4) & (5) & (6) & (7) & (8) & (9) \\
\hline Panel A & Rents & & & & & & & & \\
\hline Airbnb Count (x100) & $\begin{array}{l}0.036^{* * * *} \\
(0.008)\end{array}$ & $\begin{array}{l}0.035^{* * * *} \\
(0.009)\end{array}$ & $\begin{array}{l}0.037^{* * *} \\
(0.009)\end{array}$ & $\begin{array}{l}0.036^{* * *} \\
(0.009)\end{array}$ & $\begin{array}{l}0.058^{* * *} \\
(0.020)\end{array}$ & $\begin{array}{l}0.051^{* * * *} \\
(0.024)\end{array}$ & $\begin{array}{l}0.034^{*} \\
(0.018)\end{array}$ & $\begin{array}{l}0.038^{* * * *} \\
(0.008)\end{array}$ & $\begin{array}{l}0.053^{* * *} \\
(0.010)\end{array}$ \\
\hline $\mathrm{N}$ & 2.123 & 2.123 & 2.123 & 2.123 & 2.123 & 2.123 & 2.123 & 2.123 & 1.920 \\
\hline Panel B & \multicolumn{9}{|c|}{ Transaction Prices } \\
\hline Airbnb Count (x100) & $\begin{array}{l}0.110^{* * * *} \\
(0.019)\end{array}$ & $\begin{array}{l}0.085^{* * * *} \\
(0.016)\end{array}$ & $\begin{array}{l}0.039^{* *} \\
(0.017)\end{array}$ & $\begin{array}{l}0.040^{* *} \\
(0.018)\end{array}$ & $\begin{array}{l}0.052^{* * * *} \\
(0.020)\end{array}$ & $\begin{array}{l}0.062^{* *} \\
(0.025)\end{array}$ & $\begin{array}{l}0.082^{* * * *} \\
(0.025)\end{array}$ & $\begin{array}{l}0.063^{* * *} \\
(0.017)\end{array}$ & $\begin{array}{l}0.084^{* * * *} \\
(0.022)\end{array}$ \\
\hline $\mathrm{N}$ & 7.901 & 7.901 & 7.901 & 7.901 & 7.901 & 7.901 & 7.901 & 7.901 & 7.228 \\
\hline Panel C & \multicolumn{9}{|c|}{ Posted Prices } \\
\hline Airbnb Count (x100) & $\begin{array}{l}0.081^{* * * *} \\
(0.010)\end{array}$ & $\begin{array}{l}0.068^{* * * *} \\
(0.009)\end{array}$ & $\begin{array}{l}0.032^{* * *} \\
(0.010)\end{array}$ & $\begin{array}{l}0.026^{* * *} \\
(0.010)\end{array}$ & $\begin{array}{l}0.022 \\
(0.019)\end{array}$ & $\begin{array}{l}0.005 \\
(0.023)\end{array}$ & $\begin{array}{l}0.084^{* * *} \\
(0.21)\end{array}$ & $\begin{array}{l}0.045^{* * * *} \\
(0.010)\end{array}$ & $\begin{array}{l}0.075^{* * * *} \\
(0.012)\end{array}$ \\
\hline $\mathrm{N}$ & 2.229 & 2.229 & 2.229 & 2.229 & 2.229 & 2.229 & 2.229 & 2.229 & 2.024 \\
\hline Time FE & $\mathrm{X}$ & $\mathrm{X}$ & $\mathrm{X}$ & $\mathrm{X}$ & $\mathrm{X}$ & $\mathrm{X}$ & $\mathrm{X}$ & $\mathrm{X}$ & $\mathrm{X}$ \\
\hline BSA FE & $\mathrm{X}$ & $\mathrm{X}$ & $\mathrm{X}$ & $\mathrm{X}$ & $\mathrm{X}$ & $\mathrm{X}$ & $\mathrm{X}$ & $\mathrm{X}$ & $\mathrm{X}$ \\
\hline Controls & - & $\mathrm{X}$ & $\mathrm{X}$ & $\mathrm{X}$ & $\mathrm{X}$ & $\mathrm{X}$ & $\mathrm{X}$ & $\mathrm{X}$ & $\mathrm{X}$ \\
\hline Trends & - & - & $X_{n, 2012}(\mathrm{~L})$ & $X_{n, 2012}(\mathrm{Q})$ & BSA (L) & BSA (Q) & - & - & - \\
\hline Detrendend BSA & - & - & - & - & - & - & $\mathrm{X}$ & - & - \\
\hline$X_{n, 2012} \times \mathrm{GDP}$ & - & - & - & - & - & - & - & $\mathrm{X}$ & - \\
\hline No Hist Dist & - & - & - & - & - & - & - & - & $\mathrm{X}$ \\
\hline
\end{tabular}

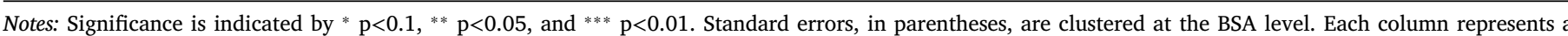

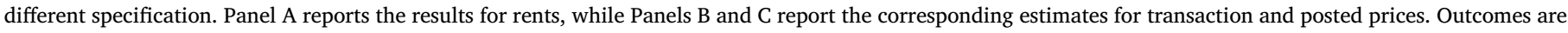

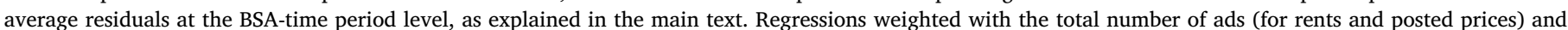

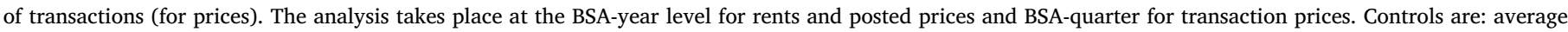

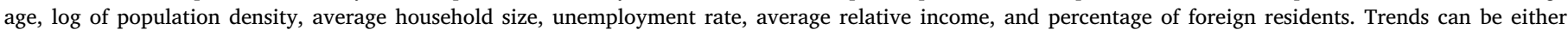

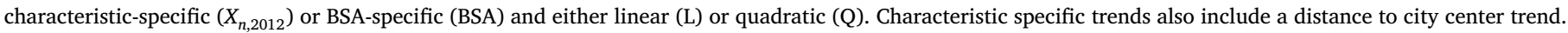

These graphs are suggestive evidence that neighborhoods with higher Airbnb penetration also experienced higher rents and price growth with the arrival and expansion of Airbnb. Since these series might be affected by other confounding factors that could be biasing the results, we move to our main empirical strategies described in Section 4.

\subsection{Baseline results}

In Table 3, we report our baseline results for the impact of Airbnb on rents (Panel A) and prices (Panels B and C). As explained above, throughout the table, the dependent variable is the average BSA-time period residual of a micro regression in which log rents (or log prices) are regressed on housing characteristics and time dummies.

In column 1, we regress the outcome of interest against the number of Airbnb listings while controlling only for time and BSA-fixed effects. Then, in column 2, we add BSA time-varying controls. Coefficients are positive and significant for both rents and prices, which implies that an increase in the number of listings translates into an increase in rents and prices. The effects on prices are larger than on rents, especially for transaction prices. The presence of contemporaneous controls has no large impact on the estimates for rents, while it slightly decreases coefficients for prices, although not in a statistically significant way. Nevertheless, we keep the socioeconomic controls in subsequent specifications for the sake of completeness.

In column 3 (4), we include socioeconomic-specific linear (or quadratic) time trends by introducing interaction terms between a linear (or quadratic) time trend and the control variables measured in 2012 as detailed in Section 4. The coefficients for prices are somewhat reduced, while they remain fairly constant for rents. Then, we report the results of specifications that fit BSA-specific time trends. Column 5 shows the results for linear trends and the results for quadratic trends are presented in column 6 . These allow for both observable and unobservable characteristics to impact neighborhood trends. The inclusion of linear time trends increases the coefficient for rents (though not significantly) and reduces the coefficients for prices, especially for posted prices where the coefficient becomes non-significant. As for regressions with quadratic trends, they do not substantially change the coefficients of rents and transaction prices but it further decreases the coefficient for posted
Table 4

Impact of Airbnb on the number of households, household size and population.

\begin{tabular}{|c|c|c|c|c|}
\hline & (1) & (2) & (3) & (4) \\
\hline Panel $A$ & \multicolumn{4}{|c|}{ Outcome: $\log$ (Number of Households) } \\
\hline Airbnb Count (x100) & $\begin{array}{l}-0.014^{* * *} \\
(0.005)\end{array}$ & $\begin{array}{l}-0.024^{* * *} \\
(0.006)\end{array}$ & $\begin{array}{l}-0.010^{*} \\
(0.006)\end{array}$ & $\begin{array}{l}-0.007^{* *} \\
(0.004)\end{array}$ \\
\hline Panel B & \multicolumn{4}{|c|}{ Outcome: $\log$ (Household Size) } \\
\hline Airbnb Count (x100) & $\begin{array}{l}-0.002 \\
(0.004)\end{array}$ & $\begin{array}{l}-0.018^{* * *} \\
(0.005)\end{array}$ & $\begin{array}{l}-0.009^{*} \\
(0.005)\end{array}$ & $\begin{array}{l}0.004 \\
(0.005)\end{array}$ \\
\hline Panel C & \multicolumn{4}{|c|}{ Outcome: $\log$ (Population) } \\
\hline Airbnb Count (x100) & $\begin{array}{l}-0.016^{*} \\
(0.009)\end{array}$ & $\begin{array}{l}-0.043^{* * *} \\
(0.009)\end{array}$ & $\begin{array}{l}-0.020^{* *} \\
(0.008)\end{array}$ & $\begin{array}{l}0.002 \\
(0.004)\end{array}$ \\
\hline $\mathrm{N}$ & 2056 & 2056 & 2056 & 2056 \\
\hline Time FE & $\mathrm{X}$ & $\mathrm{X}$ & $\mathrm{X}$ & $\mathrm{X}$ \\
\hline BSA FE & $\mathrm{X}$ & $\mathrm{x}$ & $\mathrm{x}$ & $\mathrm{x}$ \\
\hline Controls & - & $\mathrm{x}$ & $\mathrm{X}$ & $\mathrm{X}$ \\
\hline Time Trends & - & - & $X_{n, 2012}(\mathrm{~L})$ & BSA (L) \\
\hline
\end{tabular}

Notes: Significance is indicated by ${ }^{*} \mathrm{p}<0.1,{ }^{* *} \mathrm{p}<0.05$, and ${ }^{* * *} \mathrm{p}<0.01$. Standard errors, in parentheses, are clustered at the BSA level. Each cell represents a different regression with the log the number of households (panel A), the log of household size (panel B) and the log of population (panel C). The analysis takes place at the BSA-year level for the period 2009-2017. Controls are average age, unemployment rate, average relative income, and percentage of foreign residents. Linear trends can be either characteristic-specific $\left(X_{n, 2012}(\mathrm{~L})\right)$ or BSAspecific (BSA (L)). Characteristic specific trends also include a distance to city center trend.

prices. Nevertheless, by introducing quadratic trends we might be overfitting the model as a vast majority of the BSA quadratic trend coefficients are non-significant. For posted prices, where results are more sensitive to the inclusion of quadratic trends, the F-test of their joint significance is only 1.60 .

As mentioned before, one caveat of this approach is that if Airbnb impacts rent and price trends rather than levels, the BSA fixed effects will absorb part of the Airbnb effect on the outcomes. In column 7, we repeat the analysis after detrending the data following the procedure described in Section 4. In a first step, the pre-Airbnb data are used to estimate BSA-specific time trends, which are then used to detrend all data 
Table 5

Impact of Airbnb on rents and prices: IV regressions.

\begin{tabular}{|c|c|c|c|c|}
\hline & $\begin{array}{l}\text { First Stage } \\
\text { (1) }\end{array}$ & $\begin{array}{l}\text { Second Stage } \\
\text { (2) }\end{array}$ & $\begin{array}{l}\text { First Stage } \\
\text { (3) }\end{array}$ & $\begin{array}{l}\text { Second Stage } \\
\text { (4) }\end{array}$ \\
\hline Panel A & Rents & & & \\
\hline Airbnb Count (x100) & & $\begin{array}{l}0.022^{* *} \\
(0.011)\end{array}$ & & $\begin{array}{l}0.033^{* * *} \\
(0.010)\end{array}$ \\
\hline TouristAmenities $\times$ GoogleTrends & $\begin{array}{l}0.005^{* * * *} \\
(0.000)\end{array}$ & & $\begin{array}{l}0.005^{* * * *} \\
(0.001)\end{array}$ & \\
\hline $\mathrm{N}$ & 2.123 & 2.123 & 2.123 & 2.123 \\
\hline F-stat. excl. inst. & 192.2 & & 70.2 & \\
\hline Panel B & Transaction Prices & & & \\
\hline Airbnb Count (x100) & & $\begin{array}{l}0.123^{* * * *} \\
(0.020)\end{array}$ & & $\begin{array}{l}0.104^{* * *} \\
(0.023)\end{array}$ \\
\hline TouristAmenities $\times$ GoogleTrends & $\begin{array}{l}0.004^{* * * *} \\
(0.000)\end{array}$ & & $\begin{array}{l}0.003^{* * * *} \\
(0.000)\end{array}$ & \\
\hline $\mathrm{N}$ & 7.228 & 7.228 & 7.228 & 7.228 \\
\hline F-stat. excl. inst. & 217.8 & & 61.3 & \\
\hline Panel C & Posted Prices & & & \\
\hline Airbnb Count (x100) & & $\begin{array}{l}0.074 * * * \\
(0.014)\end{array}$ & & $\begin{array}{l}0.047^{* * *} \\
(0.013)\end{array}$ \\
\hline TouristAmenities $\times$ GoogleTrends & $\begin{array}{l}0.005^{* * * *} \\
(0.000)\end{array}$ & & $\begin{array}{l}0.005^{* * *} \\
(0.001)\end{array}$ & \\
\hline $\mathrm{N}$ & 2.229 & 2.229 & 2.229 & 2.229 \\
\hline F-stat. excl. inst. & 159.0 & & 70.5 & \\
\hline Time FE & $\mathrm{x}$ & $\mathrm{X}$ & $\mathrm{X}$ & $\mathrm{x}$ \\
\hline BSA FE & $\mathrm{x}$ & $\mathrm{x}$ & $\mathrm{x}$ & $\mathrm{x}$ \\
\hline Controls & $\mathrm{X}$ & $\mathrm{X}$ & $\mathrm{X}$ & $\mathrm{x}$ \\
\hline$X_{n, 2012} \times$ GDP & - & - & $\mathrm{x}$ & $\mathrm{x}$ \\
\hline
\end{tabular}

Notes: Significance is indicated by ${ }^{*} \mathrm{p}<0.1,{ }^{* *} \mathrm{p}<0.05$, and ${ }^{* * *} \mathrm{p}<0.01$. Standard errors, in parentheses, are clustered at the BSA level. Panel A reports the results for rents, while Panels B and C report the corresponding estimates for transaction and posted prices. Outcomes are average residuals at the BSA-time period level, as explained in the main text. Regressions weighted with the total number of ads (for rents and posted prices) and of transactions (for prices). The analysis takes place at the BSA-year level for rents and posted prices and BSA-quarter for transaction prices. Controls are: average age, log of population density, average household size, unemployment rate, average relative income, and percentage of foreign residents. $X_{n, 2012} \times$ GDP also includes distance to city center times GDP.

points. Here, the coefficient for rents slightly decreases and gets closer to the specifications reported in columns 1 and 2. For prices, they both increase with respect to columns 3 to 6 , and their magnitude becomes more similar to each other. While these estimates provide yet another robustness test of the results, we acknowledge that the pre-Airbnb period is admittedly short to reliably estimate the pre-trends needed to detrend the post-Airbnb data.

The arrival and expansion of Airbnb coincides with the period of economic recovery that started in 2013. One concern is that economic growth might have impacted rents and prices differently across the city. In column 8 , we add an interaction term between each control variable in 2012 (including the distance to the city centre) with the log of regional GDP. This allows us to control for areas reacting differently to economic growth. Our coefficients are still positive, strongly significant and of a similar magnitude after this inclusion. Finally, in a last sensitivity test, we also show that our findings are not driven by neighborhoods in the historical city center (Ciutat Vella), characterised by very high levels of Airbnb activity. The results reported in column 9 show that coefficients are still significant and of a similar magnitude after BSAs in the more central parts of the city are excluded.

To interpret the economic size of the estimated effects, we focus on the results in column 2 . At face value, our estimates imply that an increase in 100 Airbnb listings in a given neighbourhood translates to increases of $3.5 \%$ in rents, $8.5 \%$ in transaction prices and $6.8 \%$ in posted prices. Given that the average increase in Airbnb activity in the period 2012-2016 is of 54 listings, our estimates imply an average increases of $1.89 \%$ in rents, $4.59 \%$ in transaction prices and $3.67 \%$ in posted prices.

The large degree of heterogeneity in Airbnb activity across BSAs implies that Airbnb has not affected all neighborhoods equally. In Fig. A. 2 in the Appendix we illustrate these heterogeneous impacts by plotting the result of multiplying the coefficients obtained in column 2 by the Airbnb activity of each BSA in 2016. While the implied effects are very close to zero for the less central BSAs, our estimates imply some local impacts that are substantial. For the High Airbnb Areas, Airbnb has increased rents, transaction prices and posted prices by an average of $7 \%, 17 \%$ and $14 \%$, respectively.

Across the different specifications, the results indicate that higher Airbnb penetration leads to increases in both rents and prices, with the effects on prices being larger than on rents. These results are an empirical test of the predictions of our theoretical model of Section 2. The results suggest that the net effect of Airbnb activity positively affects rents and prices, which implies that the possible negative externalities associated with Airbnb do not offset its inflationary effects. Since housing units that are on Airbnb yield, on average, a higher return than those units that are rented to residents, the housing price increase due to Airbnb exceeds that of long-term rents.

The results of specifications with BSA-specific linear time trends in column 5 are close to those reported in column 2, which corresponds to a more parsimonious specification with BSA and time fixed effects and time-varying control variables. Overall, we consider the estimates in column 2 as our baseline results for two reasons. First, the time period before the expansion of Airbnb (i.e., $\leq 2012$ ) might be too short to obtain robust estimates of BSA-specific time trends. Second, and most importantly, the event-study exercises shown below indicate that the parallel trends assumption holds before 2013, suggesting that specifications that fit neighborhood specific time trends are unnecessary.

Finally, we perform a formal test á la Oster to assess the robustness of the results to omitted variable bias. The method, developed by Oster (2019) and inspired by Altonji et al. (2005), analyzes how the inclusion of controls changes the coefficient of interest and the R-squared 


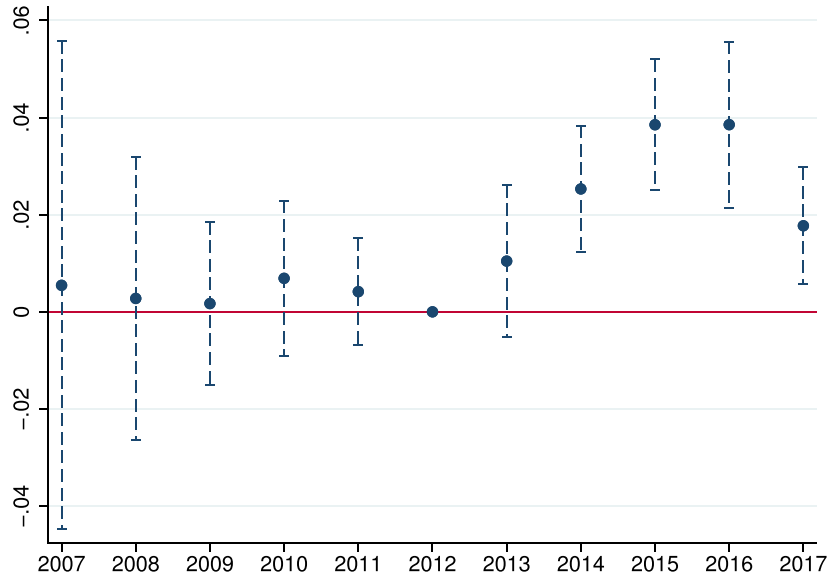

(a) Rents

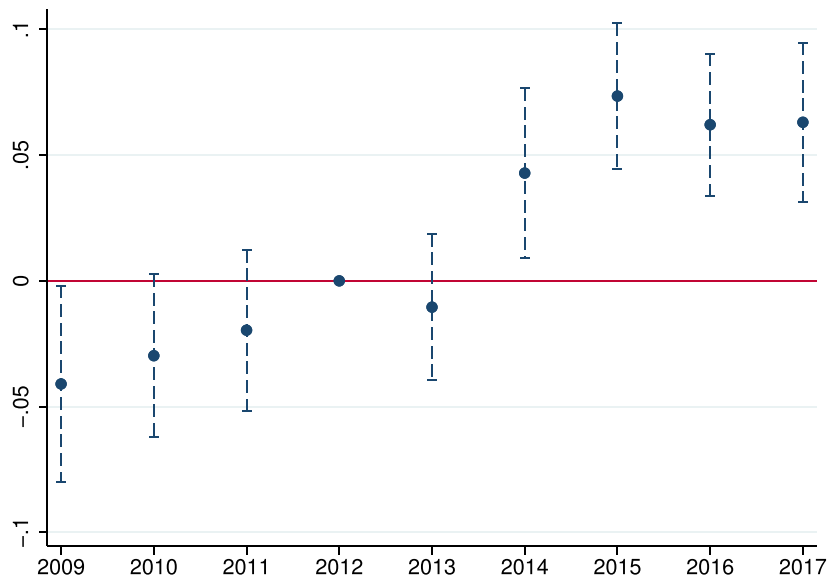

(b) Transaction Prices

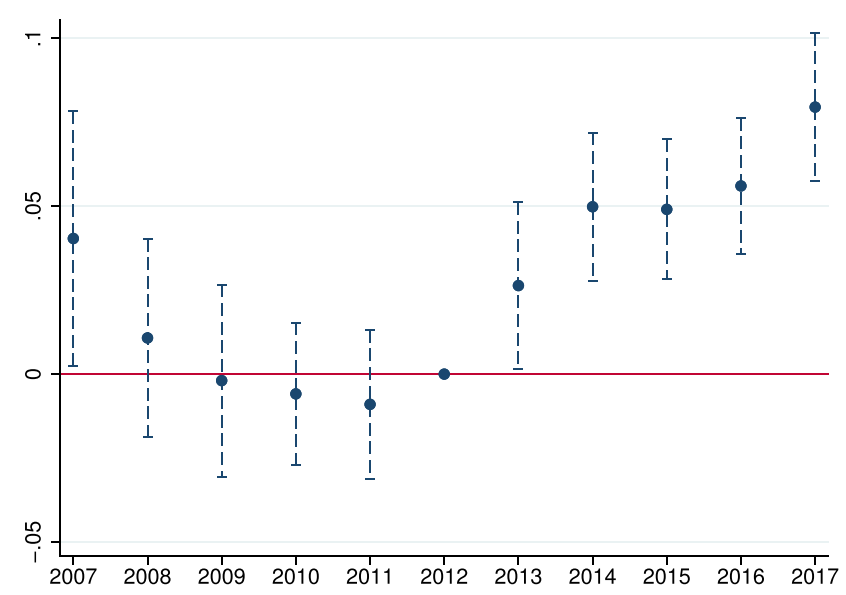

(c) Posted Prices

Fig. 6. Event-study graph for rents and prices Notes: Outcome variables Rents, Transaction and Posted prices are expressed in logs. Event-study regressions following Eq. 9, in which we interact year dummies with the level of Airbnb activity for 2016.

of the main regression. If including controls increases the predictive capacity of the model while not affecting the coefficient of interest, it is less likely that including unobservables would bias the results. One way to assess this potential bias is to compute the relative importance of unobservables to observables $(\delta)$ that would be consistent with a coefficient of interest equal to zero $(\beta=0)$. This is equivalent to asking how important the unobservables would need to be relative to the observables to eliminate the estimated effect.

For our baseline specification (column 2 in Table 3), the $\delta$ that matches $\beta=0$ amounts to 6.77 for rents, 1.41 for transaction prices and 39.7 for posted prices. ${ }^{28}$ It means that the importance of unobservables would have to be $6.8,1.4$ and 39.7 times higher than that of the observables for the coefficients to be null. These high values occur because controls have a very large explanatory power while their inclusion has a small influence on our Airbnb coefficients. This exercise indicates that concerns about omitted variables bias are limited since the values of $\delta$

\footnotetext{
${ }^{28}$ We compare a constrained specification (with time dummies only) with an unconstrained specification which also includes BSA fixed effects and all the time varying controls at the BSA level $\left(X_{n, t}\right)$. As proposed by Oster (2019), we set $R_{\max }^{2}=1.3 \times R^{2}$.
}

are larger than one. This also suggests that gentrification is unlikely to explain the bulk of our effects.

\subsection{Alternative Airbnb measures}

In this subsection, we show that the results are robust to alternative measures of Airbnb activity. So far, our measure of Airbnb activity reflected contemporaneous activity. Each BSA-time cell is matched to the number of Airbnb listings that received a review in that particular quarter. In column 2 of Table A. 1 in the Appendix, we consider a specification in which Airbnb activity is measured over a longer time window. Each BSA-time cell is matched to a moving average (MA) measure of Airbnb activity that averages contemporaneous activity with that of the previous three quarters (AbnbCount MA). The purpose of this measure is to take into account Airbnb seasonality.

Although the BSAs are relatively similar in size, we compute a measure of Airbnb density by dividing the number of listings over the total number of housing units (column 3). Finally, in column 4, we take the $\log$ of the number of Airbnb listings to reproduce the log-log specification used by Barron et al. (2020). The last row of Table A.1 provides the average of each of the alternative measures of Airbnb activity to ease comparability across estimates. 


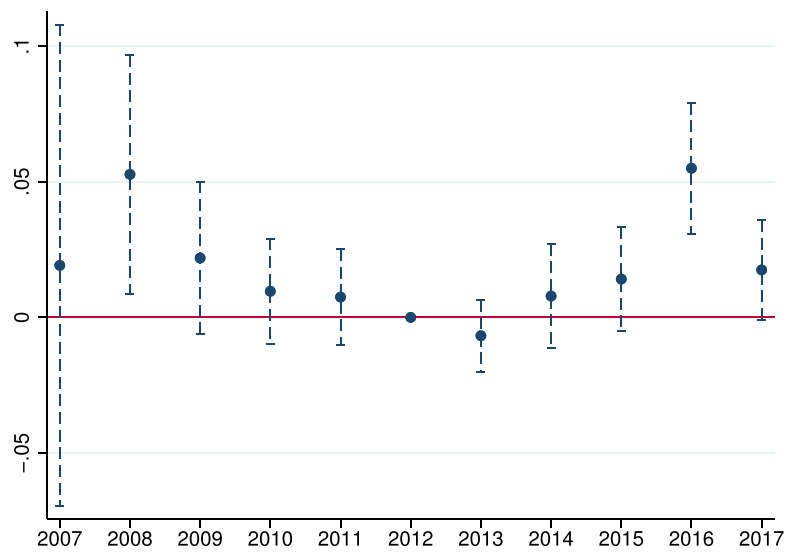

(a) Rents

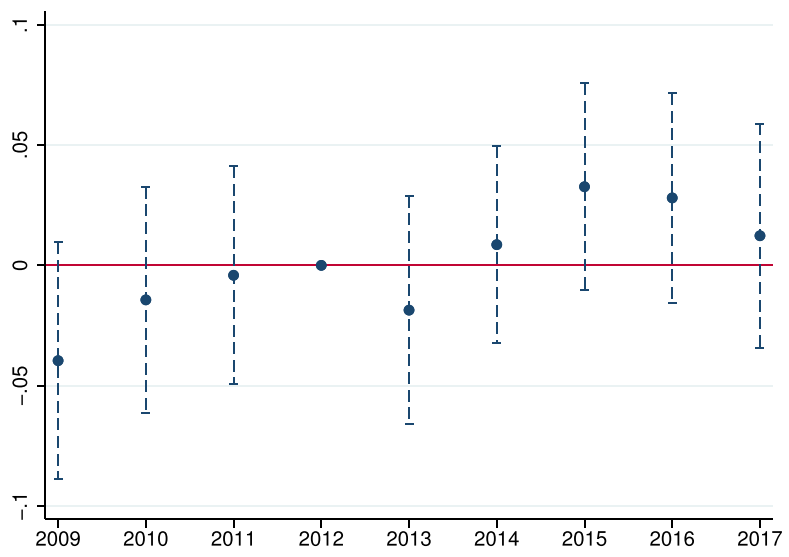

(b) Transaction Prices

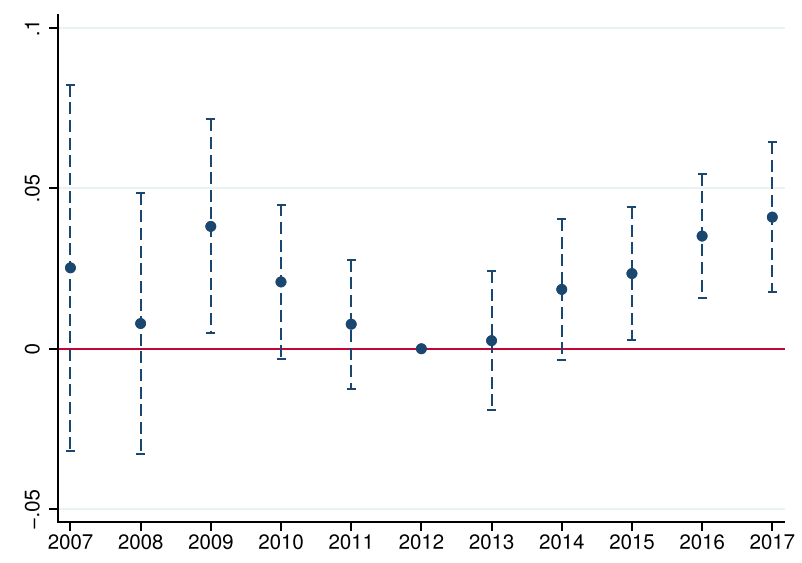

(c) Posted Prices

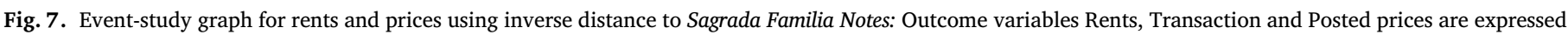
in logs. Event-study regressions following Eq. 10, in which we interact year dummies with the inverse distance to Sagrada Familia.

Overall, our findings are robust to using alternative measures of Airbnb activity. Despite the underlying differences between the two studies, our results (reported in column 4) are similar in magnitude to Barron et al. (2020) for the US. They find that a $1 \%$ increase in Airbnb listings increases housing rents and prices by $0.018 \%$ and $0.026 \%$, respectively. Our estimates are a bit lower for rents $(0.0098)$, while Barron et al. (2020)'s estimate for housing prices is in between our estimates for posted prices $(0.017)$ and transaction prices $(0.031)$.

\subsection{Mechanisms}

As explained in the theoretical model of Section 2, the impact of Airbnb on rents comes from the reduction of long-term rental supply caused by owner choice to shift to short-term rentals. To provide direct evidence of this mechanism, we would ideally look at the number of units rented to residents. Since this data is not available, we examine instead the number of households, which includes both owner-occupiers and tenant households. ${ }^{29}$ We also assess the impact on population and household size, where the latter is computed as the ratio between popu-

\footnotetext{
${ }^{29}$ Alternatively, we could look at the number of signed rental agreements from official records. However, this information is not provided at the BSA level but at the district level and only starts in 2013.
}

lation and the number of households. We argue that, while a gentrification process might reduce population and household size of the gentrifying neighborhood, as new incoming households are richer and have a lower average household size, it should not reduce the number of households in the neighborhood. Gentrifying processes revitalise neighbourhoods by attracting more households.

In Table 4, we report the results of running specifications 1, 2, 3 and 5 of Table 3 on the three different outcomes. The results of Panel A indicate that Airbnb listings have a negative and strongly significant effect on the number of households across all four specifications. If we focus on column 2, the estimates imply that 100 Airbnb listings decrease the number of households by $2.4 \%$. On the contrary, Panels B and $C$ show Airbnb's negative effect on household size and population on three of the four specifications. We can decompose the effect of Airbnb on population into the number of households plus the effect on household size. ${ }^{30}$ Then, we can compute how much of the reduction in population is due to a reduction in the number of households or due to a lower average household size. In columns 1 to 3 , the contribution of the number of households to the reduction in population is of $88 \%, 56 \%$ and $50 \%$, respectively. In column 4 , Airbnb only has a significant effect

\footnotetext{
30 The fact that pop $_{n}=$ household $s_{n} \times\left(\right.$ pop $_{n} /$ household $\left._{n}\right)$, combined with outcomes are measured in logs allows for this decomposition.
} 
Table 6

Impact of Airbnb on rents and prices: IV estimates Sagrada Familia.

\begin{tabular}{|c|c|c|c|c|c|c|}
\hline & \multicolumn{2}{|l|}{ Rents } & \multicolumn{2}{|c|}{ Transaction Prices } & \multicolumn{2}{|c|}{ Posted Prices } \\
\hline & $\begin{array}{l}(1) \\
\text { Airbnb }\end{array}$ & $\begin{array}{l}\text { (2) } \\
\operatorname{Ln}(\text { Rent })\end{array}$ & $\begin{array}{l}\text { (3) } \\
\text { Airbnb }\end{array}$ & $\begin{array}{l}(4) \\
\text { Ln(Prices) }\end{array}$ & $\begin{array}{l}\text { (5) } \\
\text { Airbnb }\end{array}$ & $\begin{array}{l}\text { (6) } \\
\text { Ln(Prices) }\end{array}$ \\
\hline Airbnb Count (x100) & & $\begin{array}{l}0.095^{* *} \\
(0.038)\end{array}$ & & $\begin{array}{l}0.120^{* *} \\
(0.052)\end{array}$ & & $\begin{array}{l}0.101^{* *} \\
(0.044)\end{array}$ \\
\hline Inv Dist SF $\times$ GoogleTrends & $\begin{array}{l}0.733^{* * * *} \\
(0.197)\end{array}$ & & $\begin{array}{l}0.452^{* * * *} \\
(0.112)\end{array}$ & & $\begin{array}{l}0.686^{* * *} \\
(0.193)\end{array}$ & \\
\hline $\mathrm{N}$ & 2.138 & 2.138 & 7.916 & 7.916 & 2.247 & 2.247 \\
\hline Time FE & $\mathrm{x}$ & $\mathrm{X}$ & $\mathrm{X}$ & $\mathrm{x}$ & $\mathrm{x}$ & $\mathrm{X}$ \\
\hline BSA FE & $\mathrm{X}$ & $\mathrm{X}$ & $\mathrm{x}$ & $\mathrm{X}$ & $\mathrm{x}$ & $\mathrm{x}$ \\
\hline Controls & $\mathrm{x}$ & $\mathrm{X}$ & $\mathrm{X}$ & $\mathrm{x}$ & $\mathrm{X}$ & $\mathrm{X}$ \\
\hline F-stat of exc. inst. & 13.8 & & 16.3 & & 12.5 & \\
\hline
\end{tabular}

Notes: Significance is indicated by ${ }^{*} \mathrm{p}<0.1,{ }^{* *} \mathrm{p}<0.05$, and ${ }^{* * *} \mathrm{p}<0.01$. Standard errors, in parentheses, are clustered at the BSA level. Each column represents a different specification. Panel A reports the results for rents, while Panels B and $\mathrm{C}$ report the corresponding estimates for transaction and posted prices. Outcomes are average residuals at the BSA-time period level, as explained in the main text. Regressions weighted with the total number of ads (for rents and posted prices) and of transactions (for prices). The analysis takes place at the BSA-year level for rents and posted prices and BSA-quarter for transaction prices. Controls are: average age, log of population density, average household size, unemployment rate, average relative income, and percentage of foreign residents.

on the number of households, suggesting again that Airbnb displaces residents.

Overall, these results strongly support the hypothesis that the channel behind the impact of Airbnb on housing prices is a supply reduction of long-term rentals. The results also lend credibility to the hypothesis that the increases in housing rents and prices that we estimate are caused by Airbnb activity and not by ongoing gentrification processes.

\section{Results for alternative empirical strategies}

\subsection{Instrumental variables results}

In Table 5, we report first and second-stage results of the instrumental variables approach described in Section 4.2. Columns 2 and 4 report the second-stage results for rents, transaction prices and posted prices, respectively. The specification corresponds to Eq. 5, where Airbnb activity is instrumented with the interaction between the cross-sectional tourist amenities index (Eq. 8) and the Google Trend searches. In columns 1 and 2, we control for BSA and time fixed effects as well as the usual control variables; in columns 3 and 4, we also include the interaction term between the control variables in 2012 (including distance to the city center) and the regional GDP level. ${ }^{31}$

Columns 1 and 3 report the first-stage coefficients. To test the relevance of the instrument we provide the F-test of excluded instruments which is well above 10, the standard rule of thumb accepted by practitioners (Angrist and Pischke, 2008). The instrument is not weak and predicts well when and where Airbnb listings appear. Moving to the second-stage results, the coefficients remain positive and statistically significant at the $1 \%$ significance level. In terms of magnitude, coefficients in column 2 are remarkably similar to their OLS counterparts of column 2 in Table 3, although admittedly the estimated coefficient for transaction prices is larger (although not in a statistically significant sense). As for column 4, the inclusion of interaction terms with GDP increases the coefficient of rents while it decreases the coefficients of prices, just like in Table 3. One concern regarding instrument validity might be that a large fraction of tourist amenities are located at the city center. The fact that our results remain stable with the inclusion of distance to the city center times GDP provides evidence that our IV estimates are not biased by a shift in preferences for the city center among residents during the recovery period.

\footnotetext{
31 These specifications correspond to columns 2 and 8 of Table 3.
}

According to Goldsmith-Pinkham et al. (2020), when discussing the exogeneity of a shift-share instrument, attention should be paid to the 'share' component of the instrument. In our case, the main concern is that BSAs that are close to tourist amenities could be experiencing different trends in housing rents and/or prices for reasons unrelated to Airbnb.

To provide some evidence of the exogeneity of our instrument, we run event-study regressions (as in Eq. 9) where we interact year dummies with an indicator variable for BSAs in the top decile of the tourist index distribution. This exercise attempts to verify whether BSAs that are closer to relevant tourist amenities were experiencing a different trend in rents and prices before the arrival of Airbnb. Panel (a) of Fig. A.3 in the Appendix shows that, before 2013, pretrends in rents were not statistically different between the two groups. In 2014, coinciding with the expansion of Airbnb, the difference becomes significant. The results are similar in Panels (b) and (c), hence lending credibility to the exogeneity hypothesis of our instrument. The results of the IV strategy provide a solid robustness test of the validity of our instrumental variables results. The fact that coefficients remain fairly similar and equally significant helps diminishing potential endogeneity concerns.

\subsection{Event-study regression results}

In this subsection, we report the results of the event study regressions (Eq. 9 in Section 4.3). Fig. 6 plots the coefficients of the interaction terms between Airbnb activity in 2016 and the year dummies for rents (a), transaction prices (b) and posted prices (c), where the coefficients in 2012 have been normalized to zero.

The interaction terms between 2016 Airbnb activity (times 100) and year dummies are statistically insignificant before 2013, while they are positive and significant starting in 2014. This indicates that, at the beginning of the period, when the number of Airbnb listings was low, rents and prices were not evolving differently in the BSAs that after 2013 had high Airbnb activity. In contrast, between 2014 and 2017, when Airbnb's presence became important, neighborhoods where Airbnb activity was concentrated started to experience higher rents and price growth. In a robustness test that is reported in Fig. A. 4 in the Appendix, we show that the results are robust to using a binary measure of Airbnb activity in 2016, where BSAs are classified into High Airbnb Areas and other areas.

The coefficients in Fig. 6 can be interpreted as follows: an increase from zero to 100 listings in 2016 increases rents by $3.8 \%$, transaction 
prices by $6.2 \%$ and posted prices by $5.6 \%$ in that year. These magnitudes are broadly in line with our baseline estimates of Table 3 .

\subsection{Sagrada Familia results}

Finally, in this sub-section we report the Sagrada Familia results. Table 6 displays the first and second-stage results of estimating Eq. 5 using the interaction between proximity to Sagrada Familia and the Google Trend searches as an instrument.

Columns 1, 3 and 5 report the first stage where our instrument is positively and significantly associated with Airbnb activity, which suggests that the instrument is relevant. The F-statistics of excluded instruments are high, which reinforces our claim. Columns 2, 4 and 6 report the second-stage results where the coefficients are positive, statistically significant and of a relatively higher magnitude than in our previous regressions, although not in a statistically significant way. Once again, the results of this exercise point in the same direction, indicating that Airbnb activity had an impact on both rents and prices in Barcelona.

Finally, Fig. 7 depicts the results of running an event-study regression using proximity to Sagrada Familia as a predictor of Airbnb activity. While the results are less conclusive in this exercise, we can nevertheless observe a similar trend than in the previous event-study where coefficients become positive and significant in 2015. This is true especially for rents and for posted prices. Yet again, this last strategy suggest that Airbnb had an inflationary effect on housing markets.

\section{Concluding remarks}

The rapid expansion of urban tourism and short-term rentals have recently garnered much interest in public opinion and among policymakers, especially in large tourist cities. Concerns about the potential negative consequences of these phenomena have led local administrations to apply a wide range of regulatory measures.

To study how Airbnb affects the city's housing markets, we examine high-quality microdata on both rents and prices and combine these data with information on the location of Airbnb activity within the city. We apply several regression-based approaches that exploit the timing and geography of the entry of Airbnb in the city to estimate the effects of this platform on the city's housing markets. The results show that Airbnb activity in Barcelona has led to an increase both in rents and housing prices, with larger effects for prices than for rents. Our preferred results indicate that, for a neighborhood with the average Airbnb activity in the city, rents have increased by $1.9 \%$, while transaction prices have increased by $4.6 \%$ and posted prices by $3.7 \%$.

Although the effects on rents are not small, they cannot explain the bulk of the high aggregate increases in rents that the city has experienced between 2012 and 2016. In the most touristic parts of the city, the effects of Airbnb are substantial. In neighborhoods in the top decile of the Airbnb activity distribution, rents are estimated to have increased by as much as $7 \%$, while increases in transaction and posted prices are as high as $17 \%$ and $14 \%$, respectively.

Short-term rental platforms such as Airbnb might worsen the housing affordability problem in cities such as Barcelona, where tourism is popular and the difference in profitability between renting long-term to residents or short-term to tourists is high. Our findings can contribute to a more informed debate about the consequences of Airbnb and the desirability and design of policies that aim to limit the size of the short-term rental market.

\section{Appendix A}

Table A.1

Impact of Airbnb on rents and prices: Robustness checks.

\begin{tabular}{|c|c|c|c|c|}
\hline & $\begin{array}{l}\text { Baseline* } \\
\text { (1) }\end{array}$ & $\begin{array}{l}\text { AbnbCount MA* } \\
\text { (2) }\end{array}$ & $\begin{array}{l}\text { AbnbDens } \\
\text { (3) }\end{array}$ & $\begin{array}{l}\log \text { AbnbCount } \\
\text { (4) }\end{array}$ \\
\hline Panel A & Rents & & & \\
\hline Airbnb & $\begin{array}{l}0.035^{* * *} \\
(0.009)\end{array}$ & $\begin{array}{l}0.029 * * * \\
(0.008)\end{array}$ & $\begin{array}{l}0.0068 \\
(0.005)\end{array}$ & $\begin{array}{l}0.0098^{* * *} \\
(0.003)\end{array}$ \\
\hline $\mathrm{N}$ & 2.123 & 2.123 & 2.123 & 2.123 \\
\hline Panel B & \multicolumn{4}{|c|}{ Transaction Prices } \\
\hline Airbnb & $\begin{array}{l}0.085^{* * * *} \\
(0.016)\end{array}$ & $\begin{array}{l}0.086^{* * * *} \\
(0.021)\end{array}$ & $\begin{array}{l}0.030^{* * *} \\
(0.005)\end{array}$ & $\begin{array}{l}0.031 * * * \\
(0.006)\end{array}$ \\
\hline $\mathrm{N}$ & 7.916 & 7.916 & 7.916 & 7.916 \\
\hline Panel C & \multicolumn{4}{|c|}{ Posted Prices } \\
\hline Airbnb & $\begin{array}{l}0.068^{* * *} \\
(0.009)\end{array}$ & $\begin{array}{l}0.070^{* * *} \\
(0.010)\end{array}$ & $\begin{array}{l}0.019 * * * \\
(0.004)\end{array}$ & $\begin{array}{l}0.017 * * * \\
(0.004)\end{array}$ \\
\hline $\mathrm{N}$ & 2.229 & 2.229 & 2.229 & 2.229 \\
\hline Time FE & $\mathrm{x}$ & $\mathrm{x}$ & $\mathrm{x}$ & $\mathrm{x}$ \\
\hline BSA FE & $\mathrm{x}$ & $\mathrm{X}$ & $\mathrm{x}$ & $\mathrm{x}$ \\
\hline Controls & $\mathrm{x}$ & $\mathrm{X}$ & $\mathrm{X}$ & $\mathrm{X}$ \\
\hline Mean 4Q2016 & 56 & 49 & $1.57 \%$ & 1.76 \\
\hline
\end{tabular}

Notes: Significance is indicated by ${ }^{*} \mathrm{p}<0.1,{ }^{* *} \mathrm{p}<0.05$, and ${ }^{* * *} \mathrm{p}<0.01$. Standard errors, in parentheses, are clustered at the BSA level. Panel A reports the results for rents, while Panels B and C report the corresponding estimates for transaction and posted prices. ${ }^{*}$ In the case of Baseline and AbnbCount MA, the coefficients are multiplied by 100 . Outcomes are average residuals at the BSAtime period level. Regressions are weighted with the total number of ads (for rents and posted prices) or transactions (for prices). The analysis takes place at the BSA-year level for rents and posted prices and BSA-quarter level for prices. Controls are average age, the log of population density, average household size, unemployment rate, average income, and percentage of foreign residents.

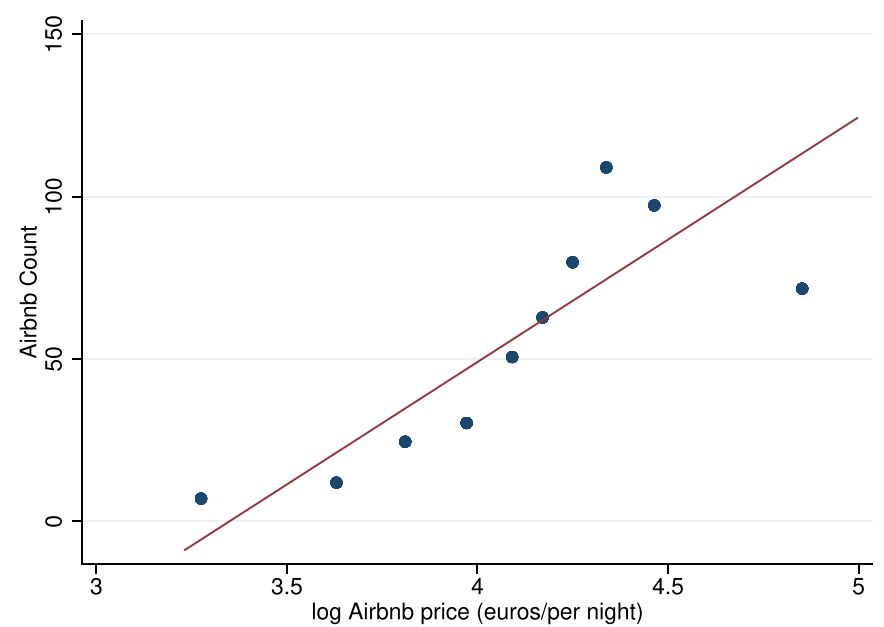

Fig. A.1. Airbnb Activity and Airbnb Prices. Notes: The graphs shows deciles of BSAs with respect to their mean Airbnb Count for the fourth quarter of 2016 ordered in the y axis. For each decile the mean log Airbnb nightly price for those active listings is shown in the $\mathrm{x}$ axis. 


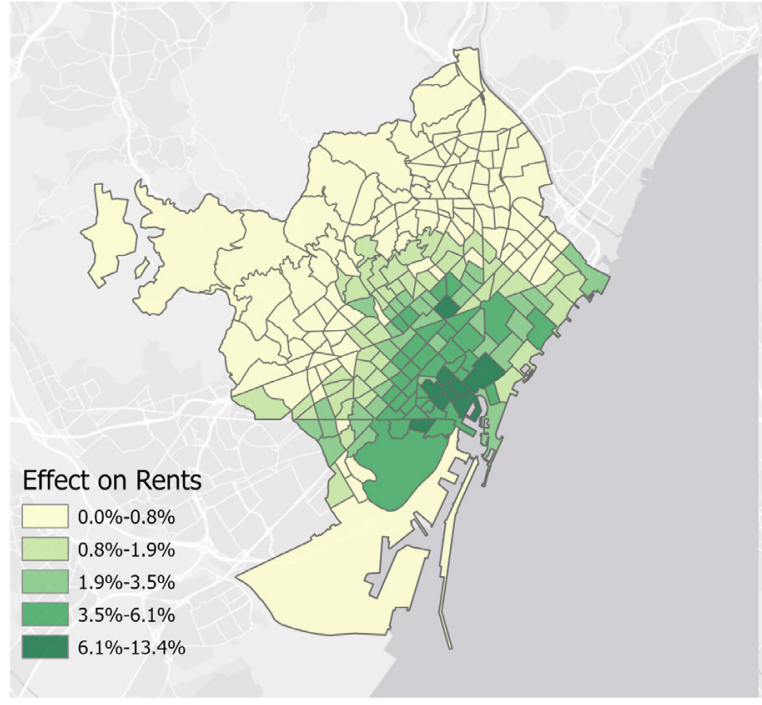

(a) Impact on Rents

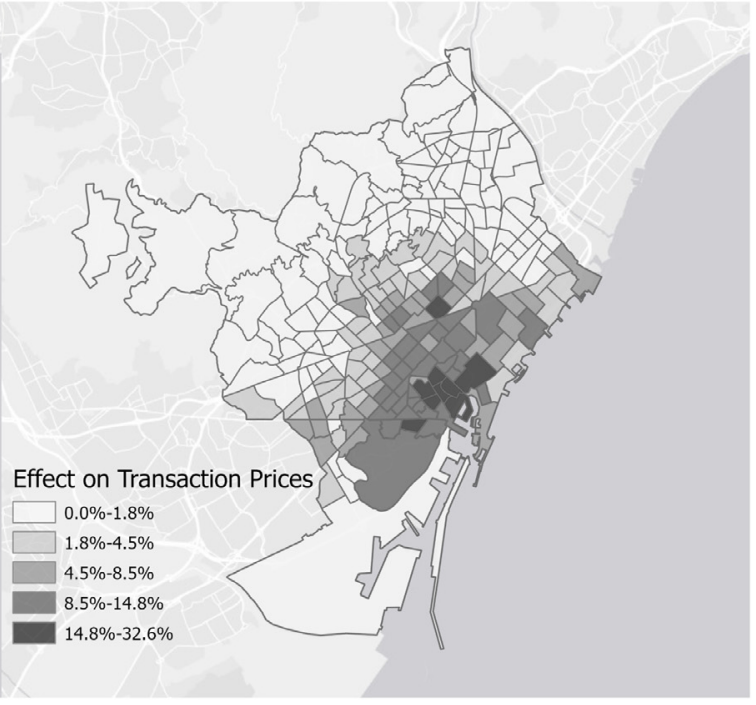

(b) Impact on Transaction Prices

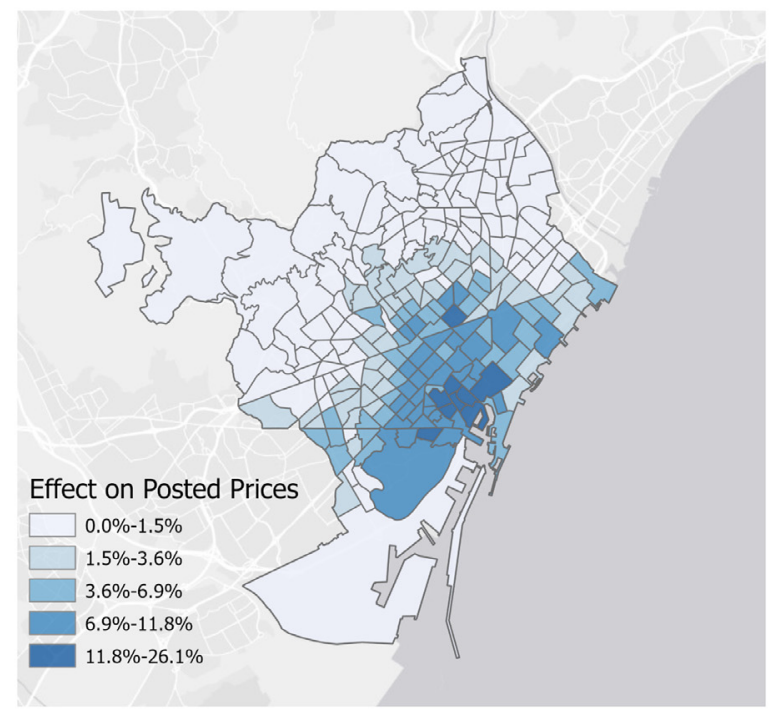

(c) Impact on Posted Prices

Fig. A.2. Implied effects of Airbnb across BSAs. Notes: These maps plot the implied impacts of Airbnb on rents and on transaction (posted) prices. For this we take the results reported in column 2 of Table 3, and multiply it by Airbnb activity in each BSA at 2016. 


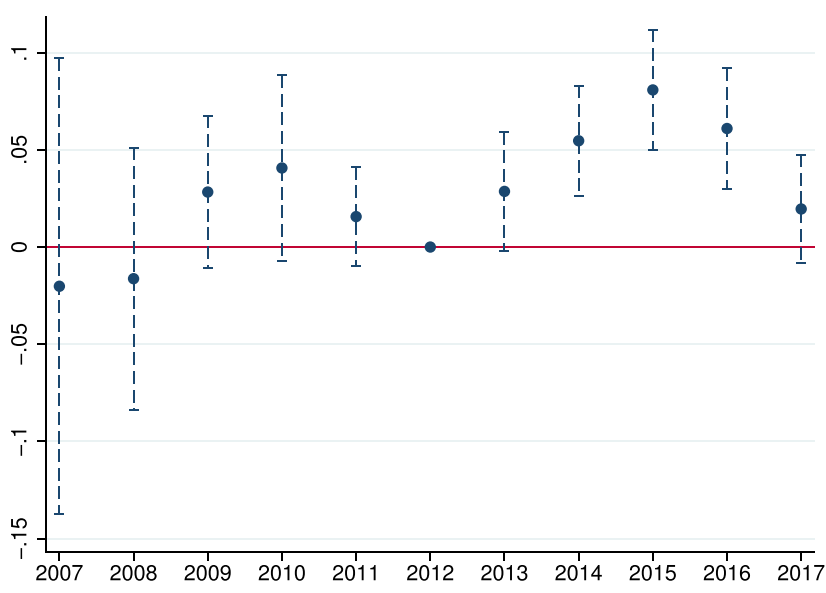

(a) Rents

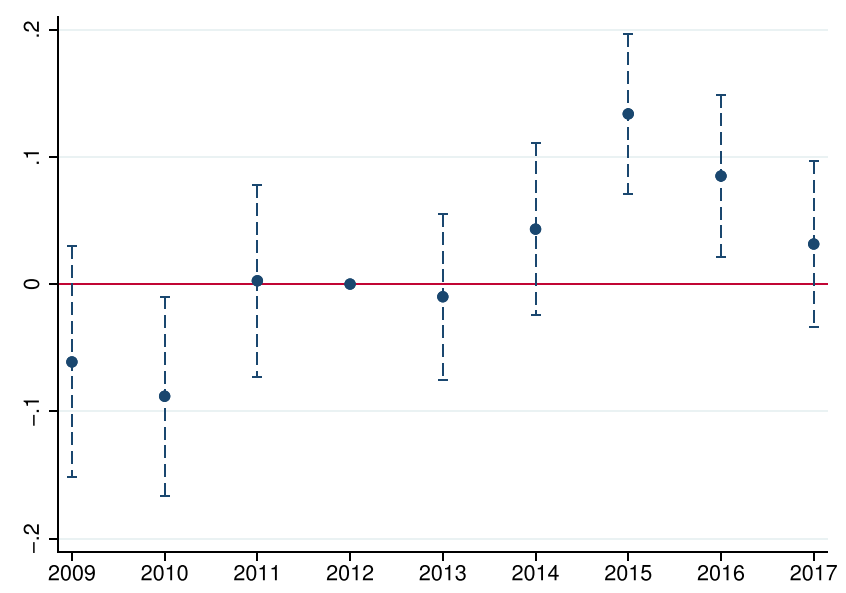

(b) Transaction Prices

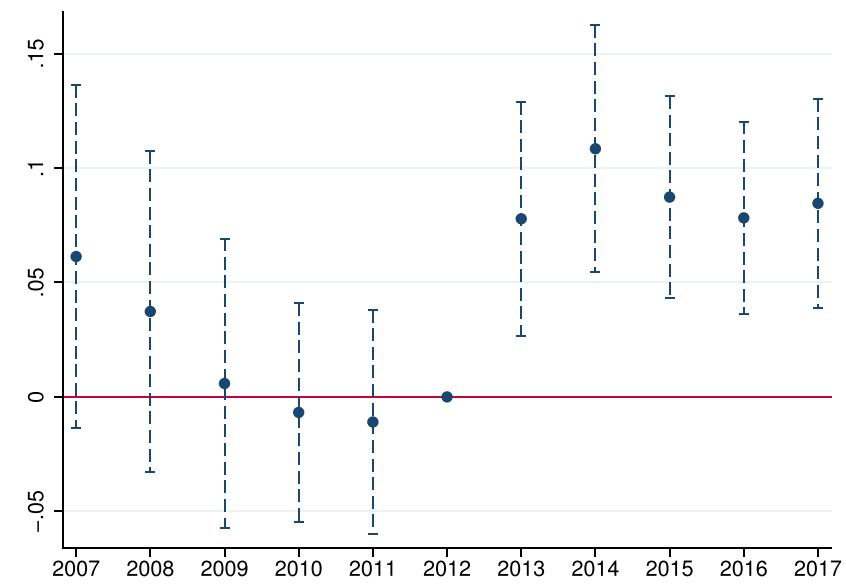

(c) Posted Prices

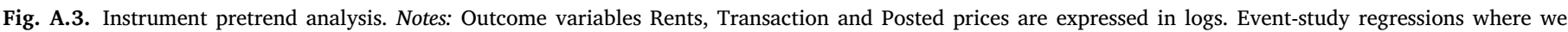
interact year dummies with an indicator variable for BSAs in the top decile of the tourist index distribution. 


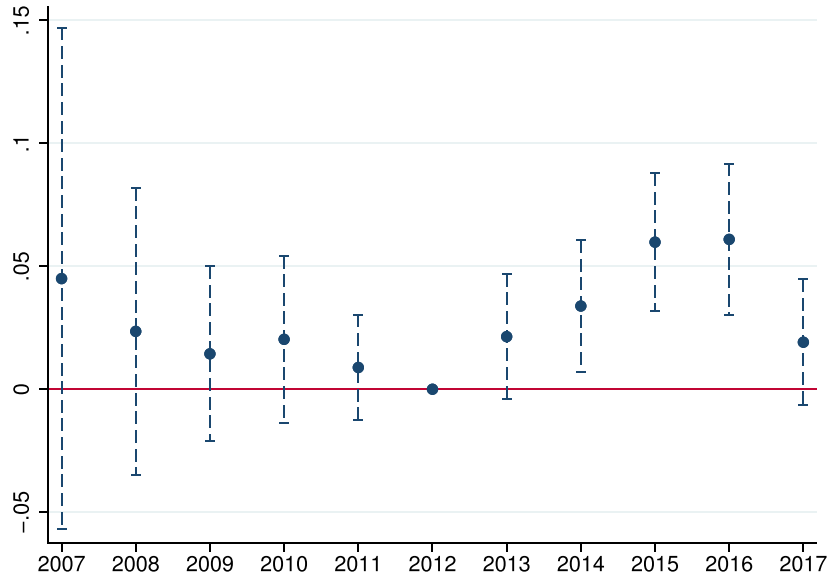

(a) $\ln$ (Rents)

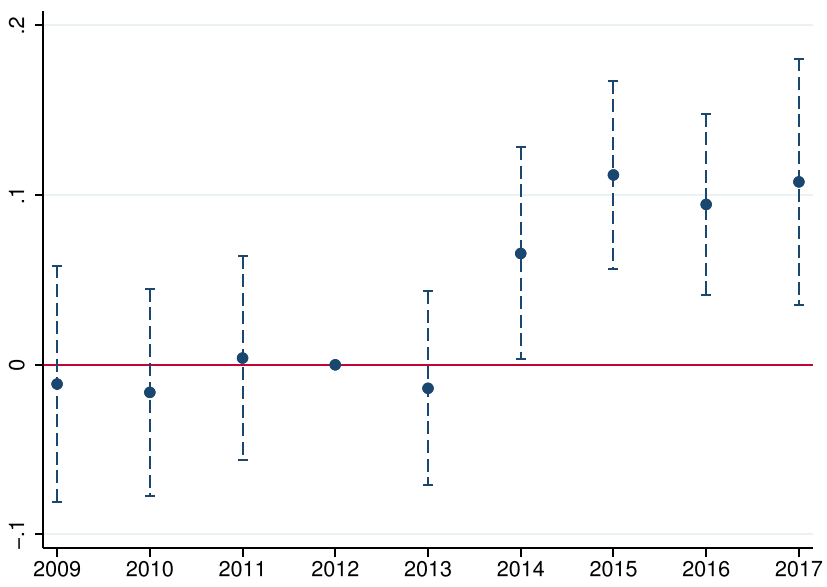

(b) $\ln$ (Prices)

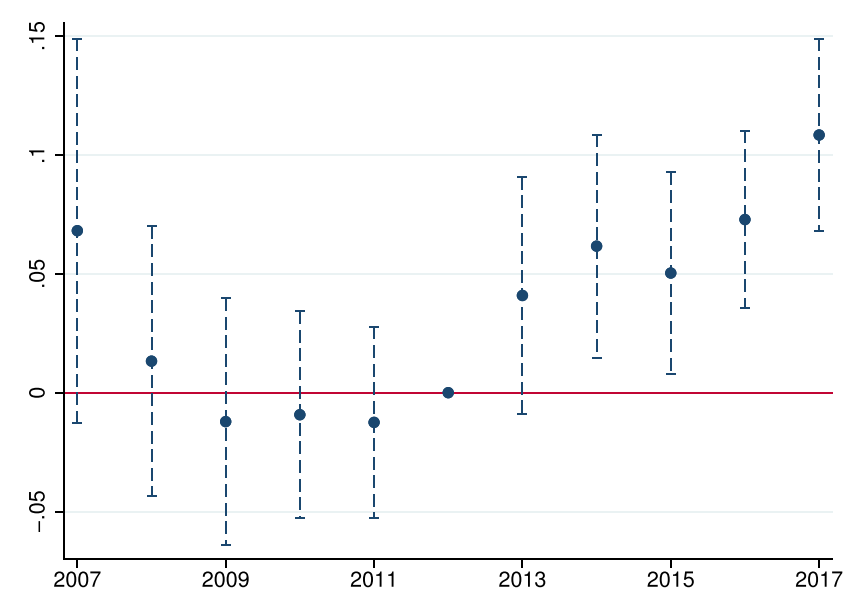

(c) $\ln$ (Posted Prices)

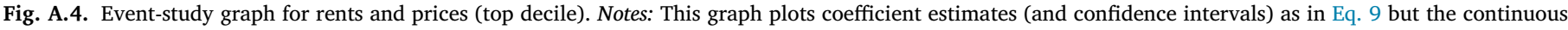

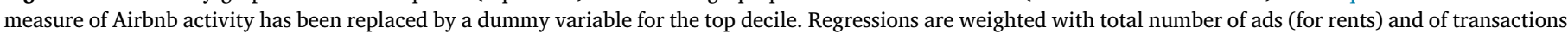
(for prices). Each point represents the difference in rents or prices between BSAs above the 90 th percentile of Airbnb listings in 2016 compared to all other BSAs.

\section{Supplementary material}

Supplementary material associated with this article can be found, in the online version, at doi:10.1016/j.jue.2020.103278.

\section{CRediT authorship contribution statement}

Miquel-Àngel Garcia-López: Conceptualization, Methodology, Formal analysis, Writing - original draft. Jordi Jofre-Monseny: Conceptualization, Methodology, Formal analysis, Writing - original draft. Rodrigo Martínez-Mazza: Conceptualization, Methodology, Formal analysis, Writing - original draft. Mariona Segú: Conceptualization, Methodology, Formal analysis, Writing - original draft.

\section{References}

Almagro, M., Domínguez-Lino, T., 2020. Location Sorting and Endogeneous Amenities: Evidence from Amsterdam. NYU, mimeo.

Altonji, J.G., Elder, T.E., Taber, C.R., 2005. An evaluation of instrumental variable strategies for estimating the effects of catholic schooling. J. Hum. Resour. 40 (4), 791-821.

Angrist, J.D., Pischke, J.-S., 2008. Mostly Harmless Econometrics: An Empiricist's Companion. Princeton University Press.

Barron, K., Kung, E., Proserpio, D., 2020. The Effect of Home-Sharing on House Prices and Rent: Evidence from Airbnb. Marketing Science forthcoming.
Baum-Snow, N., Hartley, D.A., 2020. Accounting for Central Neighborhood Change, 19802010. Journal of Urban Economics. 37 (May), 103228.

Behrens, C., Boualam, B., Martin, J., Mayneris, F., 2018. Gentrification and pioneer businesses. CEPR Discussion Paper 13296.

Bertrand, M., Duflo, E., Mullainathan, S., 2004. How Much Should We Trust Differences-In-Differences Estimates?*. $\quad$ Q. $\quad$ J. Econ. 119 (1), 249-275. doi:10.1162/003355304772839588.

Calder-Wang, S., 2020. The Distributional Impact of the Sharing Economy on the Housing Market. Harvard University, mimeo.

Chapelle, G., Eymeoud, J., 2018. Can big data increases our knowledge of the rental market? Sci. Po Mimeo.

Couture, V., Handbury, J., 2020. Urban revival in America. J. Urban Econ. 37, 103267.

Goldsmith-Pinkham, P., Sorkin, I., Swift, H., 2020. Bartik instruments: What, when, why, and how. Am. Econ. Rev. 110 (8), 2586-2624.

González-Pampillón, N., Jofre-Monseny, J., Viladecans-Marsal, E., 2020. Can urban renewal policies reverse neighborhood ethnic dynamics? J. Econ. Geogr. 20 (2), 419-457.

Kleven, H.J., Landais, C., Schultz, E., 2014. Migration and wage effects of taxing top earners: evidence from the Foreigners' tax scheme in denmark. Q. J. Econ. 129 (1), 333-378.

Koster, H., van Ommeren, J., Volkhausen, N., 2020. Short-term Rentals and the Housing Market: Quasi-experimental Evidence from Airbnb in Los Angeles. CEPR Discussion Paper 13094.

MasterCard, 2019. Global Destination Cities Index. Technical Report. MasterCard.

Monras, J., 2019. Minimum Wages and Spatial Equilibrium: Theory and Evidence. J. Labor Econ. 37 (3), 853-904.

Oster, E., 2019. Unobservable selection and coefficient stability: theory and evidence. J. Bus. Econ. Stat. 37 (2), 187-204. 
Sheppard, S., Udell, A., 2016. Do Airbnb Properties Affect House Prices. Williams College Department of Economics Working Papers 2016-03.

Wolfers, J., 2006. Did unilateral divorce laws raise divorce rates? a reconciliation and new results. Am. Econ. Rev. 96 (5), 1802-1820.
WTO, 2018. UNWTO Tourism Highlights. 2018 Edition. Technical Report. United Nations World Tourism Organization.

Zervas, G., Proserpio, D., Byers, J.W., 2017. The rise of the sharing economy: estimating the impact of airbnb on the hotel industry. J. Market. Res. 54 (5), 687-705. 